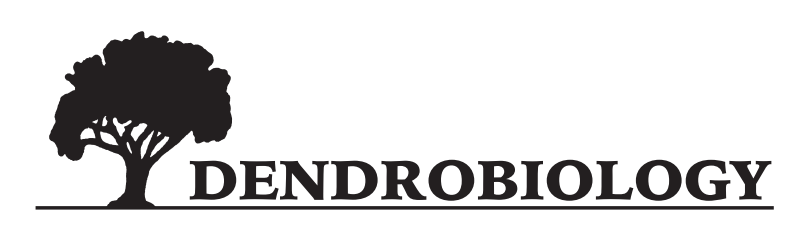

2014, vol. 72, 65-84

http://dx.doi.org/10.12657/denbio.072.006

\author{
Krystyna Boratyńska, Artur Dzialuk, Andrzej Lewandowski, \\ Katarzyna Marcysiak, Anna K. Jasińska, Karolina Sobierajska, \\ Dominik Tomaszewski, Jarosław Burczyk, Adam Boratyński
}

\title{
Geographic distribution of quantitative traits variation and genetic variability in natural populations of Pinus mugo in Central Europe
}

Received: 30 October 2013; Accepted: 15 January 2014

\begin{abstract}
Divergence in genetic as well as phenotypic structures can be expected in species with disjunctive geographic ranges and restricted gene flow among isolated populations. Dwarf mountain pine has such a disjunctive geographic range in the mountains of Central Europe. We hypothesised that populations of Pinus mugo from the Giant Mts. differ from Alpine and Carpathian populations to a greater extent than differentiation within these regions; furthermore, these differences would be detectable at both the genetic and phenotypic levels. To verify this hypothesis, the diversity and differentiation within and among eleven populations from the Giant Mts., Carpathians and Alps were analysed using 19 isozyme isozyme loci, 17 needle and 15 cone morphological characters. Moreover, the data on 10 chloroplast microsatellites used in the previous study, were reanalysed. The differences between the three regions were greater than among populations within them. The microsatellites and isozymes clearly differentiated between regions, while in the multivariate analyses of cone and needle characters the Alpine and Carpathian populations were intermingled but distinct from those sampled in the Giant Mts. The significant genetic structuring among regions may result from an ancient fragmentation and long lasting geographic isolation between the Giant Mts., Alps and Tatras. The populations from the Giant Mts., the northernmost within the geographic range of $P$. mugo, presented lower level of genetic variation then those from the Alps and Carpathians. The pattern of genetic structure observed in dwarf mountain pine may be characteristic of wind-pollinated trees with a disjunctive geographic distribution
\end{abstract}

Additional key words: genetic diversity, isozymes, isolation by distance (IBD), phenotypic diversity, chloroplast microsatellites

Addresses: K. Boratyńska, A. Lewandowski, A.K. Jasińska, K. Sobierajska, D. Tomaszewski, A. Boratyński, Polish Academy of Sciences, Institute of Dendrology, Parkowa 5, 62-035 Kórnik, Poland, e-mail: borkrys@man.poznan.pl

A. Dzialuk, J. Burczyk, Kazimierz Wielki University, Department of Genetics, Chodkiewicza 30, 85-064 Bydgoszcz, Poland

K. Marcysiak, Kazimierz Wielki University, Department of Botany, Ossolinskich 12, 85-093 Bydgoszcz, Poland 


\section{Introduction}

The major topics in evolutionary biology and conservation genetics is determining the level of genetic diversity within population and the differentiation between populations. Factors such as natural selection, genetic drift and mutations promote evolution by increasing differentiation among populations, while gene flow is an obstacle to such differentiation. It is generally accepted that genetic and morphological divergence of taxa starts with differentiation of their populations resulting from spatial isolation, which prevents, or at least strongly reduces, gene flow (Abbott et al. 2008; Comes et al. 2008). For this reason it can operate much more easily among populations within particular regions but not among regions. The level of differences between regions could additionally be intensified due to genetic drift and bottlenecks effects (Hampe and Petit 2005).

Pines are wind pollinated and produce large amounts of pollen (Koski 1970; Sugita et al. 1999; Sjögren et al. 2008). In spite of this and very effective pollen dispersal (Johansen 1991; Sjögren et al. 2008), the division of geographic range should hinder the exchange of genetic material between populations, because the effective pollen transport distance is much shorter than the potential one. Even within the same stand of P. sylvestris, transport of pollen is limited (Burczyk and Chalupka 1997; Smouse et al. 2001).

The dwarf mountain pine P. mugo Turra (= P. mugo subsp. P. mugo sensu Christensen 1987) is a prostrate, polycormic shrub which occurs in the mountain massifs of Central and Southern Europe and forms specific plant communities in the subalpine climatevegetation layer above the upper forest line (Ozenda 1988; Jirásek 1996; Poldini et al. 2004; Tsaryk et al. 2006). Inside its major occurrence centres, P. mugo can be found on the massifs, which are sufficiently high that subalpine communities of the species can be developed (Ozenda 1988; Christensen 1987; Tsaryk et al. 2006). Its lowest localities, however, can be found much below the tree line, but only under special site conditions (Gostyńska-Jakuszewska 1976; Christensen 1987). The geographic range of P. mugo is disjunctive, divided into several dozen parts (Jalas and Suominen 1973; Tsaryk et al. 2006) that have been isolated from each other from the moment the Holocene climate started to warm (Obidowicz 1996; Willis et al. 2000; Wolfrath et al. 2001; Rybníček and Rybníčková 2002; Latałowa et al. 2004).

The area of distribution of $P$. mugo repeatedly spread during periods with cool temperatures and regressed during warm periods of the Pleistocene (Willis et al. 2000; Wolfrath et al. 2001; Latałowa et al. 2004); this is similar to the case of $P$. uncinata on the Iberian Peninsula (Ramil-Rego et al. 1998; Benito Garzón et al. 2007) and follows the general role proposed by Hewitt (1996). The reduced gene flow between regions during warm periods, random genetic drift and/or possible founder effects influenced the spatial genetic and morphological structure of the populations (Young et al. 1996; Hampe and Petit 2005). The strength of particular genetic and demographic processes was probably modified by cold versus warm periods of Pleistocene (Hewitt 2000). These hypotheses seem to find confirmation in the variation of $P$. mugo. The isoenzymatic differentiation of $P$. mugo complex between the East Carpathians and Swiss Alps was found to be high (Sannikov et al. 2011), but it could also result from taxonomic differences between Carpathian ( $P$. mugo s. str.) and alpine (possibly $P$. uncinata influenced) populations. A high level of differences in chloroplast microsatellite loci between the Carpathians, Sudetes and Alps was recently described (Dzialuk et al. 2012), but rather low at selected nucleotide loci (Wachowiak et al. 2013). The significant morphological differences between $P$. mugo from the Carpathians, Sudetes and Abruzzi Mts. were also found (Staszkiewicz and Tyszkiewicz 1976; Boratyńska et al. 2005; Boratyńska and Boratyński 2007).

The populations of P. mugo in the Giant Mts. could also be younger from the Alpine and Carpathian ones, established as result of the founder events, at the end of last glacial period and forming the "leading edge" of the species geographic range (Hampe and Petit 2005). In this case they should present the low level of within-population diversity and high level of differentiation.

The aim of the study was verification of both hypotheses using isoenzyme markers as well as morphological traits of cones and needles. The cpDNA markers were reanalysed and results from all four data sets were compared using similar statistics.

\section{Material and methods}

\section{Plant material}

Samples were collected in three geographic regions: the Giant Mts. (Sudetes), the Alps and the Tatra Mts. (W Carpathians) from six, two and three populations, respectively (Table 1). Material for cpDNA, isoenzymatic and morphological examinations was collected from the same individuals, 30 or more, in each population, at distances of about 30-40 m from each other to avoid possible duplicate sampling from the same genet, as $P$. mugo frequently spreads vegetatively (Prus-Głowacki et al. 2005; Tsaryk et al. 2006). Ten two-year-old dwarf shoots with needles, ten one-year-old needles and ten cones with seeds were sampled separately from each individual. The young needles for DNA analyses were dried and stored at $-20^{\circ} \mathrm{C}$ (for details see Dzialuk et 
Table 1. Geographic location of the tested Pinus mugo populations and basic climatic data retrieved from DIVA GIS: AMT - Annual Mean Temperature; AP - Annual Precipitation; TMin - average minimal temperature of the coldest month; TMax - average maximal temperature of the warmest month; MTCQU - mean temperature of the coldest quarter (December, January, February); MTW - mean temperature of the warmest quarter (June, July, August); PWM - precipitation in the wettest month; PWQU - precipitation in the wettest quarter (June, July, August)

\begin{tabular}{|c|c|c|c|c|c|c|c|c|c|c|c|c|}
\hline Code & Location & $\begin{array}{l}\text { Voucher } \\
\text { speci- } \\
\text { mens }\end{array}$ & $\begin{array}{l}\text { Latit. (N)/ } \\
\text { Longit. (E) }\end{array}$ & $\begin{array}{l}\text { Alti- } \\
\text { tude } \\
{[\mathrm{m}]} \\
\end{array}$ & AMT & TMin & TMax & MTCQU & MTWQU & $\mathrm{AP}$ & $\begin{array}{c}\mathrm{PW} \\
\mathrm{M}\end{array}$ & $\begin{array}{l}\text { PW } \\
\text { QU }\end{array}$ \\
\hline GM 1 & $\begin{array}{l}\text { Sudetes, Giant Mts. } \\
\text { Równia below Śnieżka }\end{array}$ & $\begin{array}{c}\text { KOR } \\
48739\end{array}$ & $\begin{array}{l}50^{\circ} 44^{\prime} 44^{\prime \prime} / \\
15^{\circ} 47^{\prime} 41^{\prime \prime}\end{array}$ & $\begin{array}{l}1400- \\
1420\end{array}$ & 3.64 & -8.6 & 16.3 & -5.0 & 11.8 & 882 & 108 & 320 \\
\hline GM 2 & $\begin{array}{l}\text { Sudetes, Giant Mts. be- } \\
\text { tween Łabski Szczyt and } \\
\text { Szrenica }\end{array}$ & $\begin{array}{c}\text { KOR } \\
01465 \\
\text { KOR } \\
41988\end{array}$ & $\begin{array}{l}50^{\circ} 47^{\prime} 40^{\prime \prime} / \\
15^{\circ} 33^{\prime} 15^{\prime \prime}\end{array}$ & $\begin{array}{c}1350- \\
1450\end{array}$ & 2.43 & -8.8 & 14.1 & -5.5 & 10.2 & 984 & 115 & 338 \\
\hline GM 3 & $\begin{array}{l}\text { Sudetes, Giant Mts. } \\
\text { slopes of Śnieżka above } \\
\text { Kocioł Łomniczki }\end{array}$ & KOR & $\begin{array}{l}50^{\circ} 44^{\prime} 40^{\prime \prime} / \\
15^{\circ} 47^{\prime} 50^{\prime \prime}\end{array}$ & $\begin{array}{c}1300- \\
1500\end{array}$ & 3.64 & -8.6 & 16.3 & -5.0 & 11.8 & 882 & 108 & 320 \\
\hline GM 4 & $\begin{array}{l}\text { Sudetes, Giant Mts. } \\
\text { Kocioł Małego Stawu near } \\
\text { Samotnia }\end{array}$ & KOR & $\begin{array}{l}50^{\circ} 44^{\prime} 41^{\prime \prime} / \\
15^{\circ} 47^{\prime} 34^{\prime \prime}\end{array}$ & 1200 & 3.64 & -8.6 & 16.3 & -5.0 & 11.8 & 882 & 108 & 320 \\
\hline GM 5 & $\begin{array}{l}\text { Sudetes, Giant Mts. Czar- } \\
\text { ny Kocioł Jagniątkowski }\end{array}$ & KOR & $\begin{array}{l}50^{\circ} 47^{\prime} 05^{\prime \prime} / \\
15^{\circ} 35^{\prime} 30^{\prime \prime}\end{array}$ & 1180 & 3.08 & -8.7 & 15.2 & -5.2 & 11.1 & 928 & 111 & 326 \\
\hline GM 6 & $\begin{array}{l}\text { Sudetes, Giant Mts. Wiel- } \\
\text { ki Kocioł Snieżny }\end{array}$ & KOR & $\begin{array}{l}50^{\circ} 46^{\prime} 55^{\prime \prime} / \\
15^{\circ} 34^{\prime} 00^{\prime \prime}\end{array}$ & 1250 & 2.63 & -8.8 & 14.5 & -5.4 & 10.5 & 971 & 114 & 336 \\
\hline TM 1 & $\begin{array}{l}\text { Carpathians, Tatra Mts. } \\
\text { Dolina Pięciu Stawów } \\
\text { Polskich }\end{array}$ & $\begin{array}{c}\text { KOR } \\
41987\end{array}$ & $\begin{array}{l}49^{\circ} 13^{\prime} 09^{\prime \prime} / \\
20^{\circ} 03^{\prime} 05^{\prime \prime}\end{array}$ & $\begin{array}{c}1680- \\
1710\end{array}$ & 1.04 & -10.9 & 13.2 & -7.0 & 8.9 & 1440 & 195 & 526 \\
\hline TM 2 & $\begin{array}{l}\text { Carpathians, Tatra Mts. N } \\
\text { slopes of Grześ-Wołowiec } \\
\text { ridge }\end{array}$ & KOR & $\begin{array}{l}49^{\circ} 13^{\prime} 07^{\prime \prime} / \\
19^{\circ} 45^{\prime} 50^{\prime \prime}\end{array}$ & $\begin{array}{l}1600- \\
1650\end{array}$ & 1.12 & -11.0 & 13.5 & -7.0 & 9.1 & 1433 & 195 & 523 \\
\hline A 1 & $\begin{array}{l}\text { Alps, NW slopes of } \\
\text { Kreuzspitze Mt }\end{array}$ & & $\begin{array}{l}47^{\circ} 31^{\prime} 30^{\prime \prime} / \\
10^{\circ} 55^{\prime} 12^{\prime \prime}\end{array}$ & $\begin{array}{c}1850- \\
1900\end{array}$ & 3.15 & -8.4 & 15.8 & -4.5 & 10.7 & 1134 & 149 & 417 \\
\hline A 2 & $\begin{array}{l}\text { Alps, SW slopes of Hoch- } \\
\text { konig Mt }\end{array}$ & & $\begin{array}{l}47^{\circ} 26^{\prime} 00^{\prime \prime} / \\
13^{\circ} 05^{\prime} 00^{\prime \prime}\end{array}$ & 1500 & 2.51 & -10.5 & 16.6 & -5.8 & 10.6 & 1467 & 175 & 515 \\
\hline A 3 & Passo di Pramollo & KOR & $\begin{array}{l}46^{\circ} 32^{\prime} 45^{\prime \prime} / \\
13^{\circ} 15^{\prime} 35^{\prime \prime}\end{array}$ & 1530 & 3.47 & -9.4 & 17.6 & -4.7 & 11.5 & 1208 & 138 & 407 \\
\hline
\end{tabular}

al. 2012). The seeds were extracted from the cones and stored at $-20^{\circ} \mathrm{C}$ until further isoenzymatic analyses. The empty cones were used for biometrical analyses. The length of ten two-year-old needles, each from a different dwarf shoot, were measured immediately after collection and then put into $70 \%$ alcohol to preserve them until anatomical analyses.

\section{Laboratory treatment}

\section{Isozymes}

Due to particular feature of the conifer seeds, each mother tree was analysed using no less than 10 macrogametophytes, to reconstruct it diploid genotype (Pastorino and Gregorius 2002). The tissue was homogenised using Tris $/ \mathrm{HCl}$, ( $\mathrm{pH}$ 7.5) homogenising buffer containing 4\% PVP (K-15), 0.07\% Na-EDTA, $0.2 \%$ DTT and $0.13 \%$ albumin. The separation of isozymes on starch gels was conducted using two buffer systems. The first was in electrode buffer of $\mathrm{pH} 8.2$ containing $0.3 \mathrm{M}$ boron acid, $0.06 \mathrm{M}$ lithium hydroxide and in gel buffer balanced with citric acid to $\mathrm{pH} 8.2$, containing $0.03 \mathrm{M}$ Tris and $10 \%$ electrode buffer (Ridgeway et al. 1970). The second system was in electrode buffer of $\mathrm{pH} 7.5$ containing 0.013 $\mathrm{M}$ Tris and $0.043 \mathrm{M}$ citrate acid, and the gel buffer was prepared by a 1:10 dilution of electrode buffer in distilled water (Siciliano and Shaw 1976). The electrophoresis has been conducted using currents with an amperage of $60 \mathrm{~mA}$ and voltage of $250 \mathrm{~V}$ for the first and $120 \mathrm{~V}$ for the second buffer system.

Thirteen enzyme systems were studied (Enzyme Commission number and locus abbreviations are put in parentheses): alcohol dehydrogenase (EC 1.1.1.1, $A d h$ ), fluorescent esterase (EC 3.1.1.2, Fle), glutamate dehydrogenase (EC 1.4.1.2, Gdh), glutamate oxalo-acetate transmitase (EC 2.6.1.1, Got 1, Got 2, Got 3), isocitrate dehydrogenase (EC 1.1.1.42, Idh), leucine aminopeptidase (EC 3.4.11.1, Lap 1, Lap 2), menadione reductase (EC 1.6.99.2, Men), malate dehydrogenase (EC 1.1.1.37, Mdh 1, Mdh 3), 6-phospholuconate dehydrogenase (EC 1.1.1.44, 6Pdh 1, 6Pgd2), phosphoglucoisomerase (EC 5.3.1.9, Pgi), phosphoglucomutase (EC 2.7.5.1, Pgm 1, Pgm 2), shikimate dehydrogenase (EC 1.1.1.25, Shdh) and sorbitol dehydrogenase (EC 1.1.1.14, Srdh). 


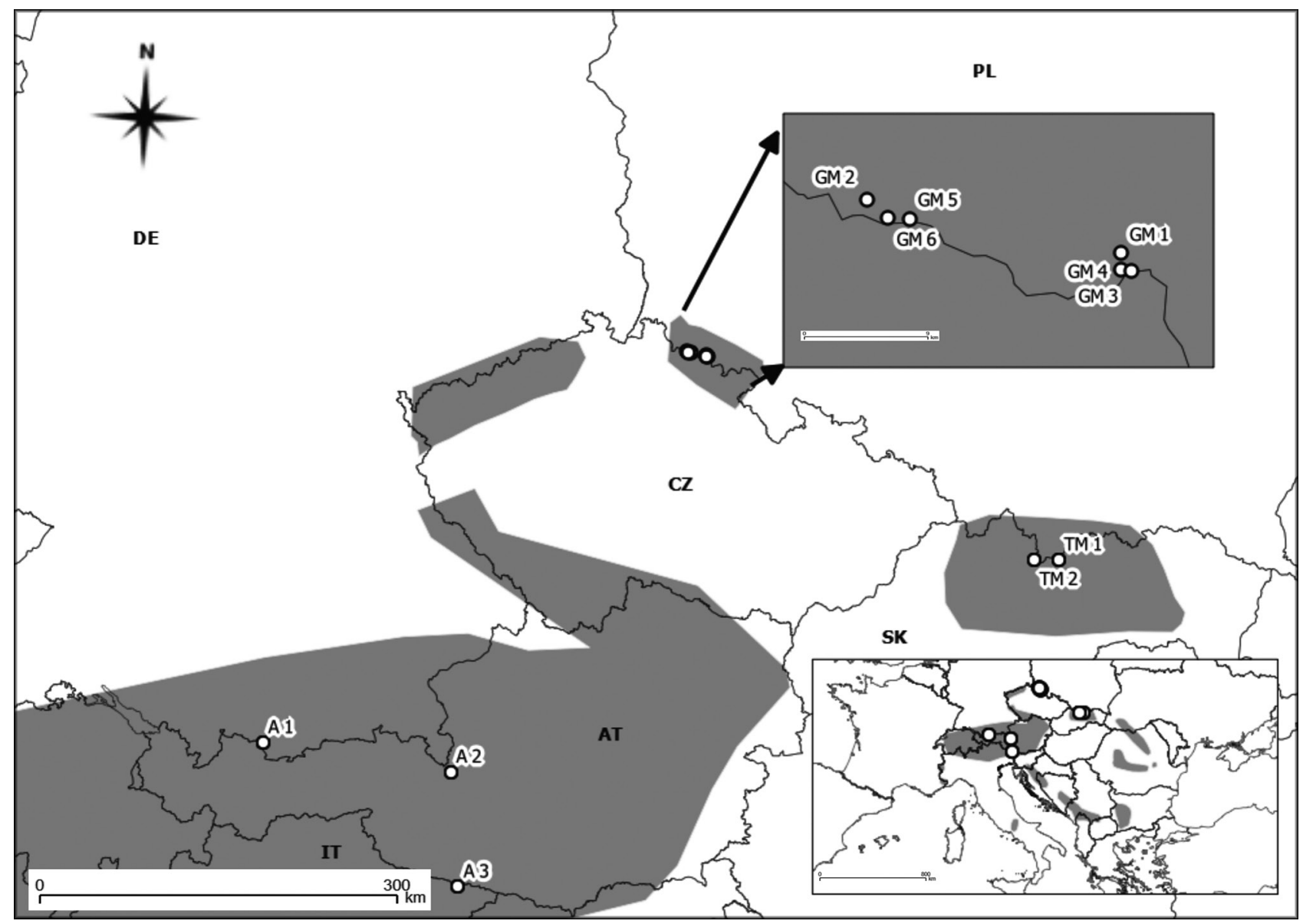

Fig. 1. Distribution of Pinus mugo (shaded area, after Jalas and Suominen (1973), simplified) and the sites sampled in the study; acronyms as in Table 1

The electrophoresis of Fle, Gdh, Got, Lap, Pgi, Pgm and $S r d h$ was conducted in the first buffer system, and Adh, Mdh, Men, 6Pgd and Shda in the second. Each gel was cut after electrophoresis and every slice was coloured to the activity of another enzyme using a standardised set of painting mixtures (Cheliak and Pitel 1984). The separation of isozymes on starch gels and genetic interpretation of the results were performed as described by Odrzykoski (2002). Alleles at each locus were numbered according to their electrophoretic migration, and the most anodally migrating band was named 1 , the next 2 , and so on.

\section{cpDNA}

Details on amplification of 10 cpSSR loci in a single multiplex PCR reaction are given elsewhere (Dzialuk et al. 2009, 2012).

\section{Phenotypic characteristics}

The needles and cones of every individual within a sample were characterised separately. Specimen variation was determined on the basis of ten needles, each from a separate brachyblast, and on the basis of ten cones. In total, morphological differentiation of $P$. mugo was analysed on the basis of 1910, 900 and 660 needles and cones from the Giant Mts., Alps and Tatras, respectively. Some of the data had been utilised earlier to describe the variation in local populations and/or taxonomical comparisons (Boratyńska and Bobowicz 2001; Boratyńska et al. 2003, 2005) and in the Giant Mts. separately (Sobierajska and Boratyńska 2008; Sobierajska et al. 2010).

The 17 needle and 15 cone characteristics were examined (Table 2). The needle traits were selected from published papers on P. mugo agg. taxonomy (Boratyńska and Bobowicz 2001; Boratyńska and Boratyński 2007), the cone traits from papers concerning P. sylvestris (Staszkiewicz 1968) and P. mugo agg. variation and taxonomy (Marcysiak and Boratyński 2007).

\section{Statistical data analysis}

\section{Genetic diversity}

On the basis of the estimated allele frequencies in isozyme loci, the mean number of alleles per locus $(A)$, effective number of alleles per locus $\left(A_{e}\right)$, per- 


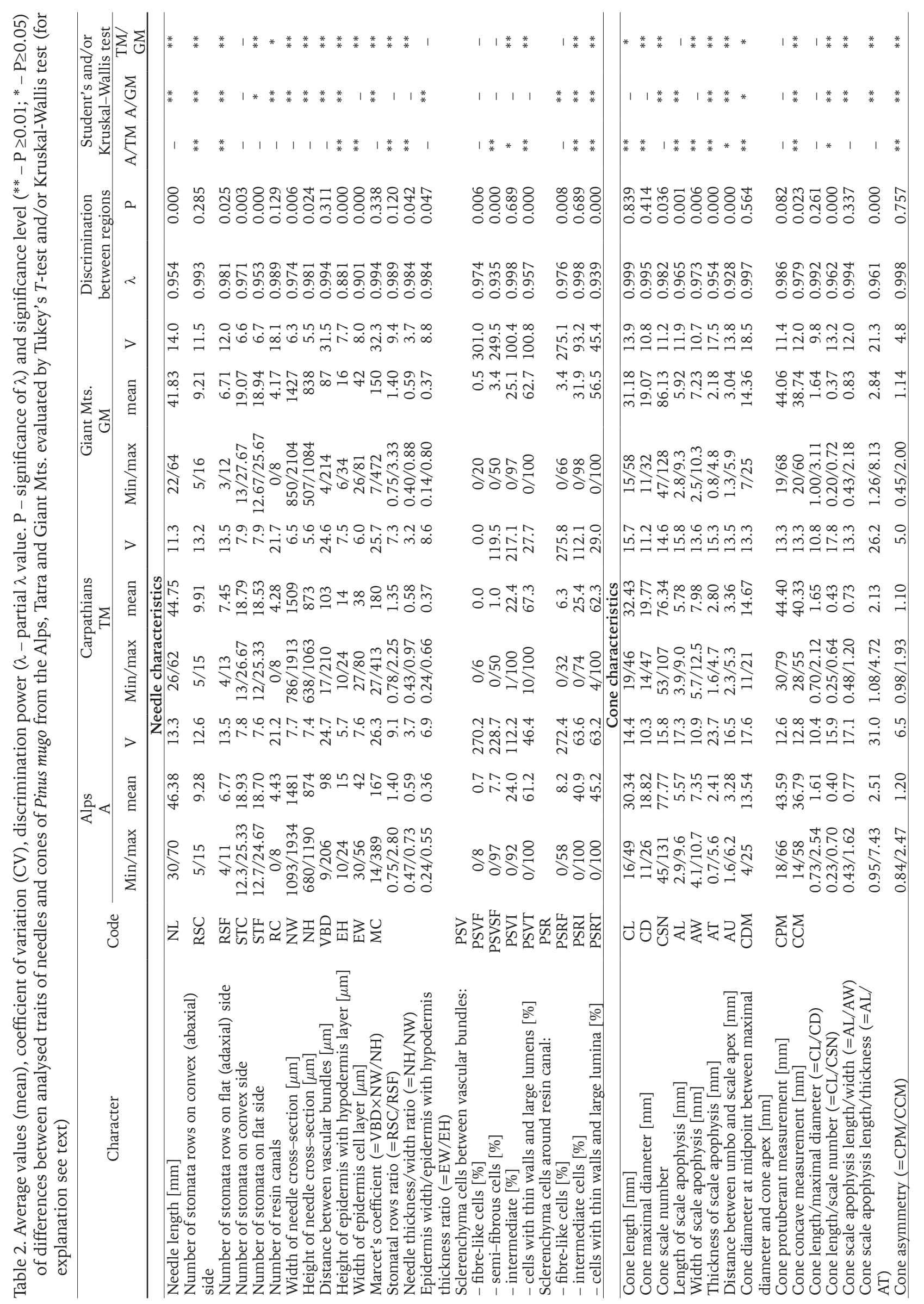


centage of polymorphic loci ( $P$, 95\% criterion), expected heterozygosity $\left(H_{\rho}\right)$, observed heterozygosity $\left(H_{0}\right)$ and fixation index $\left(F_{I S}\right)$ were calculated for each population and geographic region using GenAlEx 6.5 software (Peakall and Smouse 2012) and GDA software (Lewis and Zaykin 2001).

For chloroplast microsatellites, the data from Dzialuk et al. (2012) were reanalysed. The least squares method (Idury and Cardon 1997) was used for binning of allele lengths, then the haplotypes were identified by allele combinations of polymorphic SSRs. The variation within populations was measured by estimating the total number of haplotypes $\left(A_{h}\right)$, number of private haplotypes $\left(P_{h}\right)$, frequency of the most common haplotype in a particular population $\left(C_{h}\right)$, the effective number of haplotypes $\left(N_{e}\right)$, haplotypic richness $\left(H_{r}\right.$, Mousadik and Petit 1996), unbiased haplotype diversity $\left(H_{e}\right)$ and the mean genetic distance between individuals within populations $\left(D^{2}{ }_{s h}\right.$, Goldstein et al. 1995, applied to cpSSRs by Morgante et al. 1998).

The statistical significance of differences in the genetic parameters between geographic regions was evaluated by the Kruskal-Wallis test using the program PAST 2.17 (Hammer et al. 2001). Spatial patterns of genetic variability were visualised by Pearson's correlation analysis between intra-population parameters of genetic variation and geographic data for each population (latitude, longitude and altitude). Additional, genetic diversity parameters were regressed on climatic data retrieved from DIVA-GIS database (Hijmans et al. 2012).

\section{Morphological comparisons}

The Shapiro-Wilk's test was used to assess the symmetry and unimodality of the data The homoscedasticity of the data was checked using the Brown-Forsythe test as implemented by STATISTICA (StatSoft) to assess the possibility of using parametric statistical tests (Zar 1999; Sokal and Rohlf 2003). The arithmetic means and standard deviations were calculated for each population and region. Prior to the analyses, all data were standardized using STATISTICA (StatSoft) procedures to avoid possible influences from the various types of traits used. The level of diversity of particular characteristics was compared using the Student's t-test (Boratyńska et al. 2005).

Relationships between traits were checked using the Pearson's correlation coefficient and discrimination analysis, which also identified the power of each trait to discriminate between regions (Sokal and Rohlf 2003; Tabachnik and Fidell 2007). The possible dependence of phenotypic traits on the geographic data and climatic conditions of each population was verified via regression analysis.

\section{Differentiation and grouping of populations}

We estimated genetic structure among populations using the widely accepted Nei's $G_{S T}$ statistic. Additionally, the phylogeographic structure of chloroplast haplotypes was assessed by the permutation test of $N_{S T}$ and $G_{S T}$ values for significant differentiation. $G_{S T}$ is solely based on allele frequencies, while $N_{S T}$ takes into account similarities or relatedness among haplotypes. A $N_{S T}$ higher than the estimated $G_{S T}$ suggests that allele size mutations contributed to population differentiation; thus alleles within populations are more related than alleles in the overall sample. The program Permut \& CpSSR v. 2.0 (Pons and Petit 1996) was applied to compare $G_{S T}$ vs. $N_{S T}$ values using 10,000 random permutations. Because Jost (2008) has shown that, when using highly polymorphic markers, $G_{S T}$ does not provide a straightforward assessment of how different populations are, we also computed the $D$ estimator. The significance of $D$ estimates was evaluated using bootstrap resampling in GenAlEx 6.5 (Peakall and Smouse 2006, 2012) and SPADE (Chao and Shen 2010).

The hypothesis that dwarf pines from the same geographic region (mountain range) are more closely similar genetically and morphologically was tested using three approaches. First, their genetic differentiation was quantified using a hierarchical analysis of molecular variance (AMOVA). Total genetic variation was partitioned into (1) among regions (Tatra Mts., Giant Mts., Alps), (2) among populations within regions, and (3) within populations. The significance was tested by resampling with 1,000 randomizations using the program Arlequin ver. 3.5.1.2 (Excoffier and Lischer 2010). The distribution of variation of every phenotypic trait between regions, populations and individuals was tested by ANOVA.

Second, to determine if genetic differences between populations corresponded to geographic distribution patterns, the genetic distance $(D)$ of Nei (1972) for isozymes and cpSSRs and Euclidean distance $\left(D_{E U}\right)$ for morphological traits were used to construct unrooted trees using the NEIGHBOR and DRAWTREE options in the PHYLIP package v 3.68 (Felsenstein 1995). The neighbour joining (NJ) method was used for building trees, because Kalinowski (2009) has recently shown the algorithm describes genetic relationships between populations that have an isolation-by-distance structure more faithfully than UPGMA. To analyze how well a tree fit the genetic data the tree was calculated from, the $\mathrm{R}^{2}$ parameter was calculated using the TreeFit program (Kalinowski 2009). If $\mathrm{R}^{2}$ is near 1.0, the tree represents a good summary of the genetic relationships shown in the distance matrix. Values less than 0.90 suggest the tree should not be used to describe population struc- 
ture. The statistical confidence in the topology of the trees was also measured by bootstrapping 10,000 NJ trees in PowerMarker v.3.25 software (Liu and Muse 2005). The CONSENSE software from the PHYLIP v 3.68 package (Felsenstein 1995) was used to construct consensus trees.

Third, to confirm the spatial pattern of genetic grouping, a principal coordinate analysis (PCoA) was performed and the ordination of the populations on the first two principal coordinates was plotted using GenAlEx 6.5 software (Peakall and Smouse 2012). To test whether population differentiation was caused by isolation by distance (IBD, Wright 1943), we conducted a Mantel test by regressing the genetic differentiation between populations $\left(F_{S T} /\left(1-F_{S T}\right)\right.$ for isozymes and cpSSRs $\left(D_{E U} /\left(1-D_{E U}\right)\right.$ for traits $)$ versus the log geographic distance. The test was carried out on 9,999 permutations of the data with GenAlEx 6.5 software (Peakall and Smouse 2012).

Additionally, the significance of differences between mathematical means of morphological traits for the three regions was verified using the t-Student's for non-biased and the Kruskal-Wallis tests for biased data (Sokal and Rohlf 2003).

\section{Results}

\section{Genetic diversity within populations}

Estimates of genetic diversity within populations are shown in Table 3. Among 19 isozyme loci, Pgi 1 was monomorphic in the whole sampled populations and thus excluded from further statistical analyses. Additionally, Got 1, Mdh 1, Pgi 2, Pgm 1 were monomorphic in at least one population. The most highly polymorphic was Adh 2, with 7 alleles, and Gdh, Got 2, Shdh 1, each with 6 alleles. On average, all loci had at least 3 alleles. Averaged across all populations, the percentage of polymorphic loci (95\% criterion) was $86 \%$, with the minimum percentage in GM 1 (79\%) and the maximum in TM 1 and A 1 (92\%). At the regional level, the mean percentage of polymorphic loci was slightly higher in the Tatras Mts. region (90\%) than in populations from the Giant Mts. (85\%) and the Alps (88\%) (Table 3). Among 98 alleles identified in tested populations of P. mugo, 12 were identified as private (3 in the Tatras Mts., 3 in the Giant Mts. and 6 in the Alps) and 15 as region private (6 in the Giant Mts., 3 in the Tatras Mts. and 6 in the Alps).

Across populations, allele number per locus ranged between 2.7 and 3.0. On average, the number of alleles differed significantly between regions (Kruskal-Wallis test: $\chi^{2}=6.2, p=0.035$ ), being the highest in the Alps. A similar pattern was observed for effective number of alleles $\left(\chi^{2}=6.4, p=0.039\right)$.

Table 3. Estimates of genetic diversity for eleven P. mugo populations and means for three geographic regions (bold) based on twenty-four isozyme loci and nine chloroplast microsatellites

\begin{tabular}{|c|c|c|c|c|c|c|c|c|c|c|c|c|c|c|c|}
\hline \multirow{2}{*}{ Region/Pop } & \multicolumn{7}{|c|}{ isozymes } & \multicolumn{8}{|c|}{ cpSSR } \\
\hline & $\mathrm{N}$ & $\mathrm{A}$ & $A_{E}$ & $\mathrm{P}_{95}(\%)$ & $\mathrm{H}_{\mathrm{o}}$ & $\mathrm{H}_{\mathrm{e}}$ & $\mathrm{F}_{\mathrm{IS}}$ & $\mathrm{N}$ & $A_{h}$ & $\mathrm{P}_{\mathrm{h}}$ & $\mathrm{C}_{\mathrm{h}}$ & $\mathrm{N}_{\mathrm{e}}$ & $\mathrm{H}_{\mathrm{r}}$ & $\mathrm{H}_{\mathrm{e}}$ & $\mathrm{D}_{\text {sh }}^{2}$ \\
\hline GM_1 & 31 & 2.71 & 1.47 & 79 & 0.276 & 0.270 & -0.018 & 32 & 22 & 4 & 0.09 & 17.66 & 20.05 & 0.974 & 6.47 \\
\hline GM_2 & 30 & 2.71 & 1.54 & 83 & 0.310 & 0.303 & -0.028 & 31 & 21 & 3 & 0.10 & 17.47 & 19.58 & 0.974 & 4.70 \\
\hline GM_3 & 29 & 2.79 & 1.45 & 88 & 0.299 & 0.269 & $-0.083^{* *}$ & 32 & 19 & 5 & 0.09 & 16.00 & 17.42 & 0.968 & 8.03 \\
\hline GM_4 & 30 & 2.83 & 1.54 & 88 & 0.311 & 0.310 & 0.017 & 31 & 21 & 7 & 0.16 & 14.78 & 19.52 & 0.963 & 6.14 \\
\hline GM_5 & 30 & 2.67 & 1.47 & 83 & 0.318 & 0.271 & $-0.131^{* * *}$ & 33 & 20 & 1 & 0.15 & 13.78 & 17.80 & 0.956 & 9.28 \\
\hline GM_6 & 30 & 2.79 & 1.52 & 88 & 0.300 & 0.288 & -0.025 & 32 & 21 & 7 & 0.16 & 15.06 & 19.11 & 0.964 & 6.58 \\
\hline Giant Mts. & 30 & 2.75 & 1.50 & 85 & 0.302 & 0.285 & $-0.044^{* *}$ & 32 & 21 & 6 & 0.16 & 15.79 & 18.91 & 0.967 & 6.87 \\
\hline TM_1 & 29 & 3.04 & 1.59 & 92 & 0.313 & 0.310 & 0.013 & 33 & 23 & 11 & 0.15 & 16.75 & 20.51 & 0.970 & 7.05 \\
\hline TM_2 & 30 & 2.75 & 1.53 & 88 & 0.297 & 0.305 & 0.033 & 33 & 25 & 15 & 0.15 & 17.29 & 22.08 & 0.972 & 6.56 \\
\hline Tatra Mts. & 30 & 2.90 & 1.56 & 90 & 0.305 & 0.307 & 0.023 & 33 & 24 & 20 & 0.15 & 17.02 & 21.30 & 0.971 & 6.81 \\
\hline A_1 & 23 & 3.04 & 1.64 & 92 & 0.368 & 0.338 & -0.073 & 30 & 28 & 26 & 0.07 & 26.47 & 27.00 & 0.990 & 7.66 \\
\hline A_2 & 29 & 2.92 & 1.61 & 88 & 0.336 & 0.328 & -0.009 & 30 & 26 & 21 & 0.07 & 23.68 & 25.00 & 0.991 & 5.38 \\
\hline A_3 & 30 & 2.92 & 1.55 & 83 & 0.299 & 0.299 & 0.008 & 30 & 23 & 16 & 0.10 & 19.57 & 22.00 & 0.982 & 6.56 \\
\hline Alps & 27 & 2.96 & 1.60 & 88 & 0.334 & 0.322 & -0.023 & 30 & 26 & 21 & 0.10 & 23.24 & 24.67 & 0.987 & 6.54 \\
\hline Total & 29.2 & 2.83 & 1.54 & 86 & 0.311 & 0.299 & $-0.026^{*}$ & 31.5 & 22.6 & 11 & 0.12 & 18.05 & 20.92 & 0.973 & 6.77 \\
\hline
\end{tabular}

isozymes: $N$, mean number of individuals analysed per locus; $A$, mean number of alleles per locus; $A_{\mathrm{E}}$, effective number of alleles per locus; $P$, percentage of polymorphic loci (95\% criterion); $H_{\text {, }}$ observed heterozygosity; $H_{e}$, mean unbiased estimate of expected heterozygosity; $F_{I S}$, fixation index; ${ }^{*} \mathrm{p}<0.05,{ }^{* *} \mathrm{p}<0.01,{ }^{* * *} \mathrm{p}<0.001$

cpSSR: $A_{h}$, number of haplotypes, $P_{b}$, number of private haplotypes; $C_{b}$, frequency of the most common haplotype in a particular population; $N_{e}$, effective number of haplotypes; $H_{r}$, haplotypic richness; $H_{e}$, Nei's index of genetic diversity estimated without bias; $D_{s h}^{2}$, mean genetic distance between individuals within populations 
The highest observed average heterozygosity $\left(H_{o}\right)$ for a population was found in $\mathrm{A} 1\left(H_{0}=0.368\right)$ and the lowest in GM $1\left(H_{0}=0.276\right)$. Although populations from the Alps had higher values of average observed heterozygosity, no statistical differences were found for populations within regions (Kruskal-Wallis test: $\left.\chi^{2}=1.8, p=0.411\right)$. A similar pattern was observed for expected heterozygosity $\left(H_{e}\right.$; Kruskal-Wallis test: $\left.\chi^{2}=4.5, p=0.104\right)$.

Although the mean fixation index $\left(F_{I S}=-0.026\right)$ indicated a significant deficiency of homozygotes $(p<0.05)$ in the whole sample, an excess of heterozygotes was statistically significant only in populations from the Giant Mts. $(\mathrm{p}<0.01)$. Unlike other regions, the Tatras Mts. showed a deficiency of heterozygotes (but it was not significant) (Table 3). No statistical differences in fixation indices were found between populations (Kruskal-Wallis test: $\chi^{2}=3.9, \mathrm{p}=0.144$ ).

Among ten chloroplast microsatellite loci, nine were polymorphic. Prior to data analysis, the monomorphic locus (PCP 102652) was discarded. With respect to cpSSRs, we identified a total of 51 alleles (variances) with an average of 3.7 alleles per population and marker. The most highly polymorphic locus was Pt71936 with 8 followed by Pt45002 and PCP41131, each with 7 alleles. The variants were combined in 163 different haplotypes out of 4,233,600 mathematically possible combinations. From these, no haplotype was common among all populations, 121 were private (observed in a single population) and 148 were region private (observed in a single geographic region). The most common haplotype was detected in all populations from the Giant Mts. and in one population from the Tatra Mts.
At the regional level, slightly smaller numbers of haplotypes, private haplotypes and haplotypic richness were observed in the Giant Mts. (21, 6 and 18.91, respectively) than in the Tatra Mts. (24, 20 and 21.30, respectively) or the Alps (26, 21 and 24.67 , respectively). The differences between regions were statistically significant for these parameters (Kruskal-Wallis test: $\chi^{2}=7.7, p=0.020 ; \chi^{2}=8.2$, $\mathrm{p}=0.016 ; \chi^{2}=7.8, \mathrm{p}=0.020$, respectively). Similarly, a higher probability of randomly sampling two identical haplotypes $\left(N_{e}\right)$ was observed in the Giant Mts. than in the Tatras Mts. or the Alps (Kruskal-Wallis test: $\left.\chi^{2}=6.2, p=0.044\right)$. As a result of the low haplotype frequencies, very high within population diversity values were found $\left(H_{e}=0.973\right)$, with the highest values in the Alps (Kruskal-Wallis test: $\chi^{2}=6.2$, $\mathrm{p}=0.043)$. No statistical differences in genetic distance between individuals within populations were found between populations (Kruskal-Wallis test: $\left.\chi^{2}=0.2, \mathrm{p}=0.918\right)$, with mean $D_{\text {sh }}^{2}=6.77$.

The Pearson correlation analysis revealed that the genetic diversity within P. mugo populations in Central Europe is significantly positively correlated with altitude but decreases with increasing latitude (Fig. $2)$. When the mean number of alleles per isozyme locus $(A)$ and haplotypic richness $\left(H_{R}\right)$ for chloroplast DNA were correlated with the geographic variables, a positive correlation was observed versus altitude $\left(\mathrm{R}^{2}=0.560 ; \mathrm{p}=0.008\right.$ and $\mathrm{R}^{2}=0.655 ; \mathrm{p}=0.003$, respectively), while the correlation with latitude was negative $\left(R^{2}=0.497 ; p=0.015\right.$ and $R^{2}=0.665$; $\mathrm{p}=0.002$, respectively). No correlations were found between the isozyme or chloroplast genetic diversity parameters versus longitude $(\mathrm{p}=0.483$ and $\mathrm{p}=0.252$,
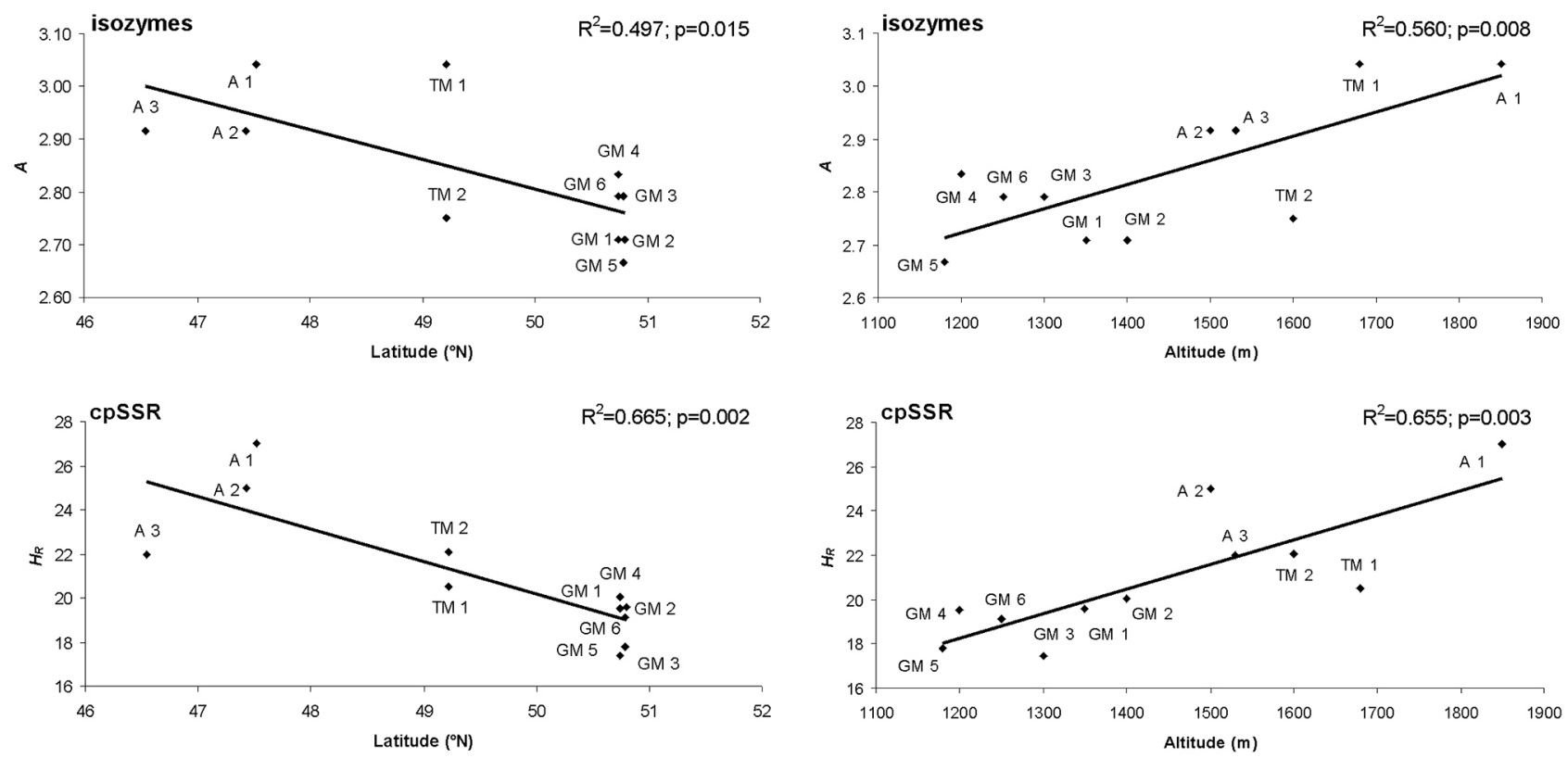

Fig. 2. Pearson's correlation analysis between mean number of alleles per isozyme locus $(A)$ and cpSSR haplotype richness $\left(H_{R}\right)$ of $P$. mugo populations versus geographic data (latitude and altitude) 
respectively). Therefore, higher intra-population diversity was observed in the Alps, with lower values in the Tatras and Giant Mts. The regression analyses revealed no effect of most climatic conditions on genetic diversity parameters. Marginally significant positive relationships between annual precipitation, precipitation in the wettest month, precipitation in the wettest quarter and the mean number of alleles per isozyme locus $\left(\mathrm{R}^{2}=0.312, \mathrm{p}=0.074 ; \mathrm{R}^{2}=0.314\right.$, $\mathrm{p}=0.073 ; \mathrm{R}^{2}=0.331, \mathrm{p}=0.064$, respectively), as well as precipitation in the wettest month and cpSSR haplotype richness $\left(\mathrm{R}^{2}=0.325, \mathrm{p}=0.067\right)$ were detected. Only haplotypic richness increased significantly with increasing annual precipitation and precipitation in the wettest quarter $\left(\mathrm{R}^{2}=0.365, \mathrm{p}=0.049 ; \mathrm{R}^{2}=0.369\right.$, $\mathrm{p}=0.048$, respectively).

\section{Morphological variation}

The most of data examined had a normal or very close to normal frequency distribution, which enabled us to use multivariate statistical methods for further analyses. Only PSV and PSR data were excluded from further analyses because of biased frequencies.

The average values of both needle and cone traits differed between the three geographic groups of populations at very low yet in most cases statistically significant levels. In the discrimination analysis, 10 characters discriminated between groups at a statistically significant level, with $\mathrm{p} \leq 0.05$. Eight out of 15 cone characteristics in the same test discriminated at a significant level between the Alps, Tatras and Giant Mts. (Table 2). Student's t-test showed that all characteristics, except for STC from needles and CPM and the $\mathrm{CL} / \mathrm{CD}$ ratio of cones, differentiated at a significant level between at least one pair of groups.

The variation in particular characteristics of needles and cones from the Alps, Tatras and Giant Mts. was found to be at similar levels. The CV values of the needle traits were statistically the same in the Alps and Tatras. The different $\mathrm{CV}$ values between the Alps and Giant Mts. have NH, WBD and MC $(\mathrm{t}=3.470, \mathrm{p}=0.008, \mathrm{t}=4.255, \mathrm{p}=0.003$ and $\mathrm{t}=4.175$, $\mathrm{p}=0.003$, respectively), and between the Tatras and Giant Mts. WBD and MC $(t=3.967, p=0.005$ and $\mathrm{t}=4.753, \mathrm{p}=0.002$, respectively). The $\mathrm{CV}$ values of the cone characteristics were also similar, with significant differences in $\mathrm{CM}$ between populations from the Alps and Tatras and between the Alps and Giant Mts. $(t=-10.61, p=0.001, t=-3.735, p=0.006$, respectively). However, significant differences in $\mathrm{CV}$ at $\mathrm{p} \leq 0.05$ were detected for CL, CDM, CPM CCM and the AL/AW ratio between Tatras and Giant Mts. populations, and for AL, CDM, and AL/AW, AL/AT and CPM/CCM ratios between Alpine and Giant Mts. populations.
The values of morphological characteristics correlated with each other. Positive, statistically significant connections were detected among groups of dimensional characteristics of needles and among dimensional characteristics of cones. The correlation between the cone and needle characters was generally weak; however, a few significant dependencies were found, as for example AT to NW and $\mathrm{NH}$ ( $\mathrm{r}_{\text {Pear- }}$ son $=0.23$ and 0.27 , respectively, $\mathrm{p} \leq 0.05$ in both cases).

The regression analysis revealed that none of the needle phenotypic characteristics correlated either to geographic coordinates or to the altitude of the analysed $P$. mugo populations, but some traits revealed a significant dependence on climatic factors. EH and EW positively correlated with the minimal temperature of the coldest month and mean temperature of the coldest quarter $\left(R^{2}=0.76, p=0.005, R^{2}=0.63, p=0.0034\right.$, and $\mathrm{R}^{2}=0.63, \mathrm{p}=0.003, \mathrm{R}^{2}=0.60, \mathrm{p}=0.005$, respectively). The same needle traits negatively correlated with the mean precipitation in the wettest month $\left(\mathrm{R}^{2}=0.56, \mathrm{p}=0.008\right)$ and wettest quarter $\left(\mathrm{R}^{2}=0.53\right.$, $\mathrm{p}=0.011$ ).

Most cone traits were dependent neither on geographic position nor climatic conditions. Only AW negatively correlated with minimal temperatures in the coldest month and quarter $\left(\mathrm{R}^{2}=0.44, \mathrm{p}=0.027\right.$ and $\mathrm{R}^{2}=0.39, \mathrm{p}=0.042$, respectively). AU correlated positively to altitude and to precipitation in the wettest month $\left(\mathrm{R}^{2}=0.52, \mathrm{p}=0.012, \mathrm{R}^{2}=0.40, \mathrm{p}=0.038\right.$, respectively), and cone asymmetry (CPM/CCM) negatively to geographic longitude and positively to maximum temperature of the warmest month, as well as to mean temperature of the driest quarter $\left(\mathrm{R}^{2}=0.58\right.$, $\mathrm{p}=0.007, \mathrm{R}^{2}=0.46, \mathrm{p}=0.023$ and $\mathrm{R}^{2}=0.56, \mathrm{p}=0.008$, respectively).

\section{Differentiation between populations}

In the overall dataset, the estimated coefficient of genetic differentiation among populations $\left(G_{S T}\right)$ was low but significant for isozymes $\left(G_{S T}=0.027\right.$, $\mathrm{p}<0.001)$ and cpSSRs $\left(G_{S T}=0.017, \mathrm{p}<0.001\right)$. Comparisons of cpSSR's $G_{S T}$ Vs. $N_{S T}\left(N_{S T}=0.022, \mathrm{p}<0.001\right)$ indicated insignificant differences ( $p>0.05)$ for haplotype differentiation measures, suggesting a lack of phylogeographic structure. Jost's $D$ was significant but much higher for chloroplast microsatellites than for isozymes $\left(D_{\text {iso }}=0.013, \mathrm{p}<0.001 ; D_{\text {cpSSR }}=0.620\right.$, $\mathrm{p}<0.001$ ).

A hierarchical AMOVA using isozymes revealed that variation among regions accounted for $4 \%$, while among populations within regions and within populations for $3 \%$ and $93 \%$ of the total variation, respectively. However, chloroplast SSRs confirmed the presence of a much more pronounced and significant differentiation among regions $\left(\Phi_{R T}=0.121 ; \mathrm{p}=0.001\right)$ (Table 4). A hierarchical ANOVA on particular traits 


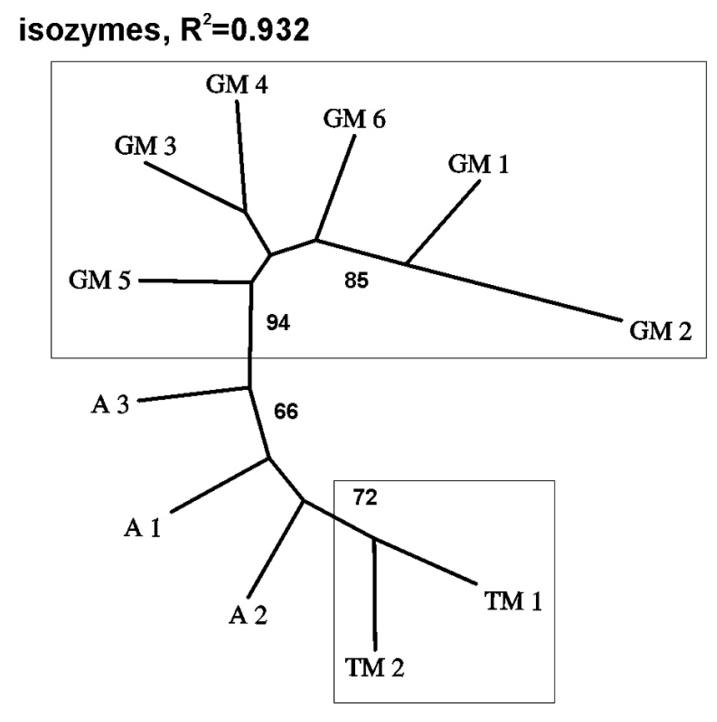

\section{needles, $R^{2}=0.936$}

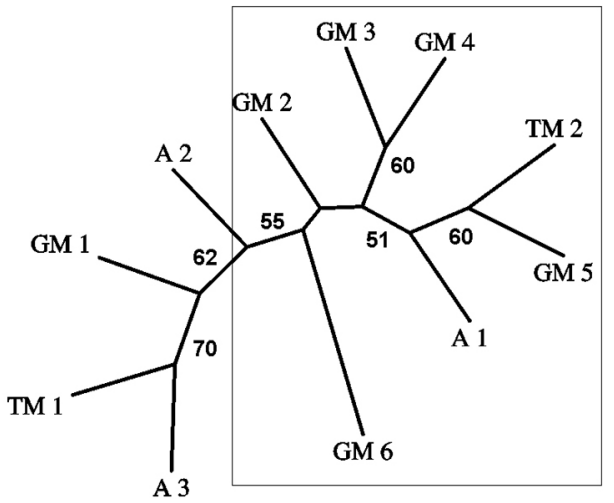

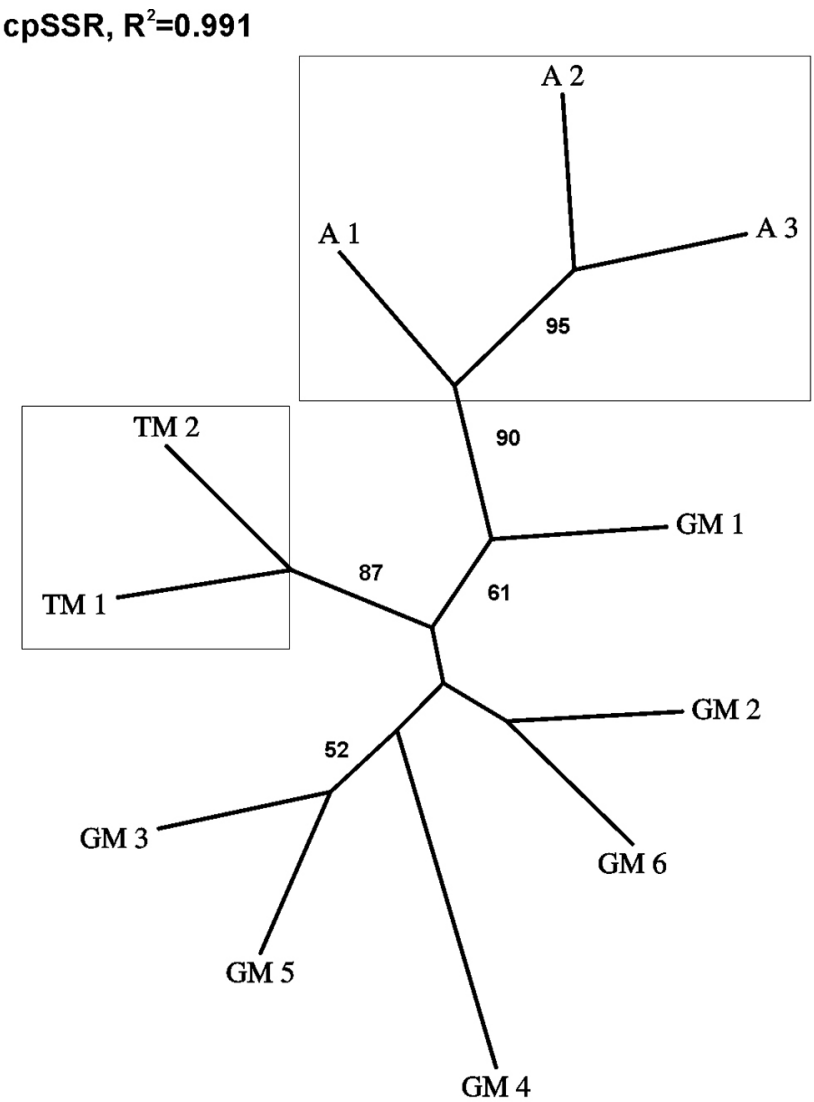

cones, $R^{2}=0.911$

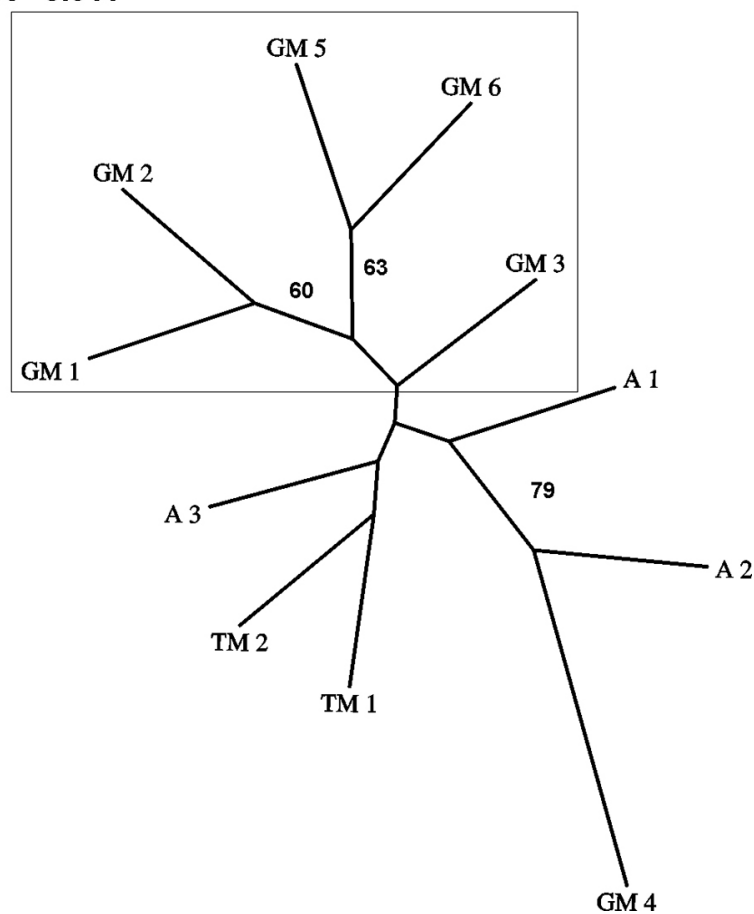

Fig. 3. Consensus of 10,000 NJ trees inferred from comparative analysis of eleven P. mugo populations. Branches are labeled with bootstrap support above $50 \%$

of needles and cones detected the major portion of variation located among individuals and then among populations (Table 5). Between the Alps, Tatras and Giant Mts. only small amounts of variation were found among the needle traits, significant only for
$\mathrm{EH}$, and among cone traits for AU and CL/CSN and CPM/CCM ratios. The distribution of variance for these characteristics revealed a higher proportion between regions than between populations within a region (Table 5). 

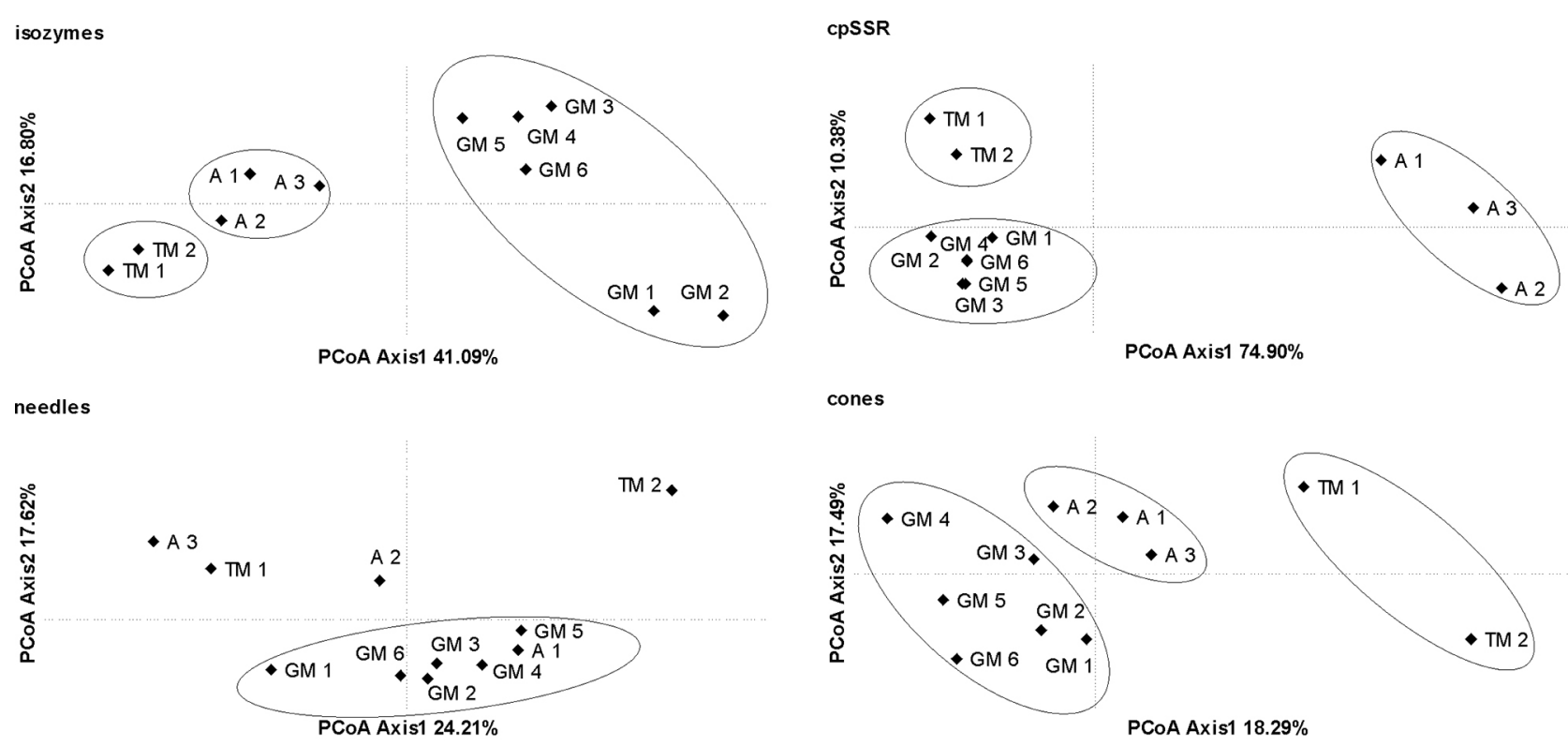

cones

Fig. 4. Principal Coordinates Analysis (PCoA) calculated from the genetic (isozymes and cpSSR) and phenotypic (needle and cone) characteristics of the $11 \mathrm{P}$. mugo populations; population acronyms as in Table 1

The pattern of population grouping is visualized in consensus NJ trees (Fig. 3). The $\mathrm{R}^{2}$ values were high (above 0.9 ) for all dendrograms, indicating accurately depicted genetic relationships between populations. In general, $\mathrm{NJ}$ analyses clustered all populations together within regions (mountain systems). Isozymes and cPSSRs revealed pronounced separation between regions, and this geographic grouping was supported by high bootstrap values (Fig. 3). The Giant Mts. region was more strongly differentiated compared with the others on all dendrograms; however, this tendency was less evident using morphological characteristics of needles and cones. There were exceptions to this geographic trend, e.g. the appearance in the Giant Mts. group of single populations from the Tatras and Alps (needle traits) or the grouping of the GM 4 population within the Alpine cluster (cone traits). Additionally, dendrograms based on morphological characteristics had lower bootstrap supports than those based on isozymes or chloroplast microsatellites. The dendrograms also revealed the Tatras region was more similar to the Alpine, forming a single mixed group, nevertheless distinct from the Giant Mts., as shown by morphological traits.
The PCoA confirmed the geographic pattern of the groupings. The first two axes of the PCoA using isozymes, cpSSR, needle and cone traits accounted for $57.89 \%, 85.28 \%, 41.82 \%$ and $35.78 \%$ of the total variance, respectively. The PCoA based on isozymes, cPSSR and cone traits clearly separated the 11 Pinus mugo populations into three groups, similar to that observed in the $\mathrm{NJ}$ analyses. The grouping of populations using needle characters was less evident. In spite of this, six populations from the Giant Mts. clustered together in a large group with a single $\mathrm{Al}-$ pine population (Fig. 4).

A significant IBD pattern was observed when genetic differentiation was correlated with the logarithm of pairwise spatial distances among populations based on isozymes $\left(\mathrm{R}^{2}=0.129 ; \mathrm{p}=0.008\right)$, cpSSRs $\left(\mathrm{R}^{2}=0.407 ; \mathrm{p}=0.002\right)$ and needle traits $\left(\mathrm{R}^{2}=0.151 ; \mathrm{p}=0.032\right)$ (Fig. 5). This correlation was significant only when all populations were analysed, regardless of region. Within regions (the Giant Mts. and Alps) there was no correlation between genetic differentiation and geographic separation. No IBD was found either using cone traits $\left(\mathrm{R}^{2}=0.030\right.$; $\mathrm{p}=0.214$ ).

Table 4. Analysis of molecular variance (AMOVA) based on isozyme and cpSSR data assuming a geographic population structuring based on isolation in three regions: Giant Mts., Tatra Mts. and Alps.

\begin{tabular}{rlrcrrr}
\hline Markers & \multicolumn{1}{c}{ Source of variance } & $d f$ & Variance component & Variation (\%) & Ф statistic & $\mathrm{p}$ \\
\hline \multirow{3}{*}{ isozymes } & Among regions & 2 & 0.316 & 4 & 0.041 & 0.001 \\
& Among populations within regions & 8 & 0.244 & 3 & 0.033 & 0.001 \\
& Within populations & 310 & 7.122 & 93 & 0.073 & 0.001 \\
\hline \multirow{3}{*}{ cpSSR } & Among regions & 2 & 0.350 & 12 & 0.121 & 0.001 \\
& Among populations within regions & 8 & 0.016 & 1 & 0.006 & 0.093 \\
& Within populations & 336 & 2.540 & 87 & 0.126 & 0.001 \\
\hline
\end{tabular}


Table 5. Analysis of variance (ANOVA) based on phenotypic needle and cone data assuming a geographical population structuring among the regions Giant Mts., Tatra Mts. and Alps.

\begin{tabular}{|c|c|c|c|c|c|c|}
\hline Trait & Source of variance & $d f$ & $\begin{array}{c}\text { Variance } \\
\text { component }\end{array}$ & Variation (\%) & F Ratio & $\mathrm{p}$ \\
\hline \multicolumn{7}{|c|}{ Needle traits } \\
\hline \multirow[t]{3}{*}{ NL } & Among regions & 2 & 3.623 & 7 & 2.2296 & 0.1642 \\
\hline & Among populations within regions & 9 & 8.917 & 17 & 9.8476 & $<.0001$ \\
\hline & Among individuals & 391 & 32.020 & 62 & 48.6020 & 0.0000 \\
\hline \multirow[t]{3}{*}{ RSC } & Among regions & 2 & 0.018 & 1 & 1.1385 & 0.3629 \\
\hline & Among populations within regions & 9 & 0.388 & 14 & 10.7650 & $<.0001$ \\
\hline & Among individuals & 391 & 1.170 & 42 & 10.8240 & 0.0000 \\
\hline \multirow[t]{3}{*}{ RSF } & Among regions & 2 & 0.068 & 4 & 1.6279 & 0.2496 \\
\hline & Among populations within regions & 9 & 0.340 & 18 & 15.6940 & $<.0001$ \\
\hline & Among individuals & 391 & 0.665 & 34 & 8.7439 & $<.0001$ \\
\hline \multirow[t]{3}{*}{ STC } & Among regions & 2 & -0.076 & -2 & 0.2023 & 0.8206 \\
\hline & Among populations within regions & 9 & 0.260 & 7 & 5.0881 & $<.0001$ \\
\hline & Among individuals & 391 & 1.900 & 51 & 12.8080 & 0.0000 \\
\hline \multirow[t]{3}{*}{ STF } & Among regions & 2 & -0.0100 & -3 & 0.2934 & 0.7527 \\
\hline & Among populations within regions & 9 & 0.414 & 11 & 7.6927 & $<.0001$ \\
\hline & Among individuals & 391 & 1.843 & 49 & 12.2460 & 0.0000 \\
\hline \multirow[t]{3}{*}{$\mathrm{RC}$} & Among regions & 2 & -0.022 & -2 & 0.4587 & 0.6464 \\
\hline & Among populations within regions & 9 & 0.119 & 10 & 6.5141 & $<.0001$ \\
\hline & Among individuals & 391 & 0.653 & 55 & 15.6930 & 0.0000 \\
\hline \multirow[t]{3}{*}{ NW } & Among regions & 2 & 1120.627 & 6 & 1.9703 & 0.1956 \\
\hline & Among populations within regions & 9 & 3582.564 & 19 & 12.9460 & $<.0001$ \\
\hline & Among individuals & 391 & 9255.427 & 50 & 20.5600 & 0.0000 \\
\hline \multirow[t]{3}{*}{$\mathrm{NH}$} & Among regions & 2 & 388.062 & 7 & 2.2224 & 0.1648 \\
\hline & Among populations within regions & 9 & 981.975 & 18 & 12.5010 & $<.0001$ \\
\hline & Among individuals & 391 & 2626.010 & 48 & 19.2700 & 0.0000 \\
\hline \multirow[t]{3}{*}{ VBD } & Among regions & 2 & 16.972 & 2 & 1.4998 & 0.2751 \\
\hline & Among populations within regions & 9 & 94.584 & 8 & 5.6584 & $<.0001$ \\
\hline & Among individuals & 391 & 616.808 & 54 & 15.7410 & 0.0000 \\
\hline \multirow[t]{3}{*}{$\mathrm{EH}$} & Among regions & 2 & 0.751 & 13 & 12.323 & 0.0028 \\
\hline & Among populations within regions & 9 & 0.187 & 3 & 6.1424 & $<.0001$ \\
\hline & Among individuals & 391 & 0.745 & 13 & 2.7248 & $<.0001$ \\
\hline \multirow[t]{3}{*}{ EW } & Among regions & 2 & 2.702 & 10 & 3.5355 & 0.0741 \\
\hline & Among populations within regions & 9 & 3.264 & 12 & 11.5690 & $<.0001$ \\
\hline & Among individuals & 391 & 8.829 & 34 & 8.4663 & $<.0001$ \\
\hline \multirow[t]{3}{*}{ MC } & Among regions & 2 & 15.413 & 0 & 1.11240 & 0.3708 \\
\hline & Among populations within regions & 9 & 396.655 & 10 & 6.9910 & $<.0001$ \\
\hline & Among individuals & 391 & 2003.946 & 52 & 14.9380 & 0.0000 \\
\hline \multirow[t]{3}{*}{$\mathrm{RSC} / \mathrm{RSF}$} & Among regions & 2 & 0.0006 & 1 & 3.2894 & 0.0877 \\
\hline & Among populations within regions & 9 & 0.0005 & 1 & 2.1442 & 0.0252 \\
\hline & Among individuals & 391 & 0.0087 & 12 & 2.5033 & $<.0001$ \\
\hline \multirow[t]{3}{*}{$\mathrm{NH} / \mathrm{NW}$} & Among regions & 2 & -0.0001 & -3 & 0.1849 & 0.8343 \\
\hline & Among populations within regions & 9 & 0.0002 & 12 & 13.3770 & $<.0001$ \\
\hline & Among individuals & 391 & 0.0004 & 25 & 4.6939 & $<.0001$ \\
\hline \multirow[t]{3}{*}{$\mathrm{EW} / \mathrm{EH}$} & Among regions & 2 & 0.000001 & 0 & 1.0847 & 0.3793 \\
\hline & Among populations within regions & 9 & 0.00015 & 4 & 6.2866 & $<.0001$ \\
\hline & Among individuals & 391 & 0.00065 & 18 & 3.2437 & $<.0001$ \\
\hline \multicolumn{7}{|c|}{ Cone traits } \\
\hline \multirow[t]{3}{*}{$\mathrm{CL}$} & Among regions & 2 & -0.0535 & -0 & 0.9074 & 0.4365 \\
\hline & Among populations within regions & 9 & 1.5050 & 5 & 3.7612 & 0.0002 \\
\hline & Among individuals & 362 & 15.7820 & 57 & 14.8010 & 0.0000 \\
\hline \multirow[t]{3}{*}{$\mathrm{CD}$} & Among regions & 2 & -0.0178 & -0 & 0.8922 & 0.4423 \\
\hline & Among populations within regions & 9 & 0.472 & 8 & 5.0576 & $<.0001$ \\
\hline & Among individuals & 362 & 3.356 & 55 & 14.2310 & 0.0000 \\
\hline
\end{tabular}




\begin{tabular}{|c|c|c|c|c|c|c|}
\hline \multirow[t]{3}{*}{ CSN } & Among regions & 2 & 22.573 & 12 & 3.8530 & 0.0613 \\
\hline & Among populations within regions & 9 & 25.762 & 14 & 10.7660 & $<.0001$ \\
\hline & Among individuals & 362 & 75.529 & 41 & 12.8820 & 0.0000 \\
\hline \multirow[t]{3}{*}{$\mathrm{AL}$} & Among regions & 2 & 0.027 & 3 & 1.6887 & 0.2376 \\
\hline & Among populations within regions & 9 & 0.120 & 12 & 8.3625 & $<.0001$ \\
\hline & Among individuals & 362 & 0.463 & 45 & 11.4320 & 0.0000 \\
\hline \multirow[t]{3}{*}{ AW } & Among regions & 2 & 0.104 & 9 & 3.2485 & 0.0861 \\
\hline & Among populations within regions & 9 & 0.151 & 15 & 10.5060 & $<.0001$ \\
\hline & Among individuals & 362 & 0.447 & 40 & 10.9330 & 0.0000 \\
\hline \multirow[t]{3}{*}{ AT } & Among regions & 2 & 0.026 & 8 & 1.9998 & 0.1909 \\
\hline & Among populations within regions & 9 & 0.091 & 29 & 24.6550 & $<.0001$ \\
\hline & Among individuals & 362 & 0.110 & 35 & 12.5640 & 0.0000 \\
\hline \multirow[t]{3}{*}{$\mathrm{AU}$} & Among regions & 2 & 0.032 & 9 & 5.2508 & 0.0298 \\
\hline & Among populations within regions & 9 & 0.021 & 6 & 4.3926 & $<.0001$ \\
\hline & Among individuals & 362 & 0.172 & 46 & 11.5430 & 0.0000 \\
\hline \multirow[t]{3}{*}{ CDM } & Among regions & 2 & -0.821 & -10 & 0.3168 & 0.7363 \\
\hline & Among populations within regions & 9 & 4.234 & 50 & 43.9110 & $<.0001$ \\
\hline & Among individuals & 362 & 2.813 & 33 & 12.2860 & 0.0000 \\
\hline \multirow[t]{3}{*}{ CPM } & Among regions & 2 & -0.481 & -1 & 0.1916 & 0.8288 \\
\hline & Among populations within regions & 9 & 1.317 & 3 & 2.6819 & 0.0050 \\
\hline & Among individuals & 362 & 22.581 & 57 & 14.0980 & 0.0000 \\
\hline \multirow[t]{3}{*}{$\mathrm{CCM}$} & Among regions & 2 & 1.444 & 4 & 3.6336 & 0.0677 \\
\hline & Among populations within regions & 9 & 1.305 & 4 & 3.0639 & 0.0015 \\
\hline & Among individuals & 362 & 17.973 & 50 & 11.9350 & 0.0000 \\
\hline \multirow[t]{3}{*}{$\mathrm{CL} / \mathrm{CD}$} & Among regions & 2 & -0.001 & -3 & 0.1889 & 0.8310 \\
\hline & Among populations within regions & 9 & 0.004 & 9 & 6.5339 & $<.0001$ \\
\hline & Among individuals & 362 & 0.021 & 48 & 10.6960 & 0.0000 \\
\hline \multirow[t]{3}{*}{$\mathrm{CL} / \mathrm{CSN}$} & Among regions & 2 & 0.0006 & 13 & 7.2883 & 0.0125 \\
\hline & Among populations within regions & 9 & 0.0003 & 6 & 4.4299 & $<.0001$ \\
\hline & Among individuals & 362 & 0.0024 & 48 & 14.3720 & 0.0000 \\
\hline \multirow[t]{3}{*}{ AL/AW } & Among regions & 2 & 0.0017 & 7 & 3.4416 & 0.0767 \\
\hline & Among populations within regions & 9 & 0.0021 & 9 & 8.0621 & $<.0001$ \\
\hline & Among individuals & 362 & 0.0082 & 36 & 7.9026 & $<.0001^{*}$ \\
\hline \multirow[t]{3}{*}{$\mathrm{AL} / \mathrm{AT}$} & Among regions & 2 & -0.0089 & -1 & 0.8778 & 0.4484 \\
\hline & Among populations within regions & 9 & 0.2552 & 38 & 37.6100 & $<.0001^{*}$ \\
\hline & Among individuals & 362 & 0.1912 & 29 & 8.6874 & $<.0001^{*}$ \\
\hline \multirow[t]{3}{*}{ CPM/CCM } & Among regions & 2 & 0.0011 & 7 & 5.7533 & $0.0234^{*}$ \\
\hline & Among populations within regions & 9 & 0.0007 & 4 & 8.3508 & $<.0001^{*}$ \\
\hline & Among individuals & 362 & 0.0015 & 10 & 2.1045 & $<.0001^{*}$ \\
\hline
\end{tabular}

\section{Discussion}

\section{Genetic diversity}

Genetic variation within most outcrossing forest tree species is high in comparison to other organisms (Hamrick and Godt 1996). The level of genetic diversity found in isozymes in the studied populations of $P$. mugo does not differ radically from that reported for another gymnosperm species characterised by a broad geographic rangeand is also similar to, but slightly higher than, levels observed earlier in the dwarf mountain pine and closely related taxa from the P. mugo agg. (Prus-Głowacki et al.1998; Lewandowski et al. 2000; Odrzykoski 2002; Slavov and Zhelev 2004). The higher level of genetic diversity in our study may result from analysing a higher number of populations representing the three distinct centres of the species' geographic range, that were probably isolated for a long period during of Pleistocene (Latałowa et al. 2004; Jankovská 2008; Jankovská and Pokorný 2008).

The non-conformity with Hardy-Weinberg proportions suggests nonrandom mating and indicates a nonequlibrium population genetic structure. However, while significant departures with excess heterozygotes were observed for the whole dataset $\left(F_{I S}=-0.026\right)$. Contrary to our results, a great deficiency in heterozygotes was observed earlier for 15 Bulgarian populations of $P$. mugo $\left(F_{I S}=0.252\right)$ and two from the Tatras Mts. $\left(F_{I S}=0.283\right)$ (Slavov and Zhelev 2004). The latter is partially consistent with our results, because we found a statistically insignificant excess of homozygotes in these mountains.

The level of diversity revealed in cPSSR loci has been discussed in a separate paper (Dzialuk et al. 

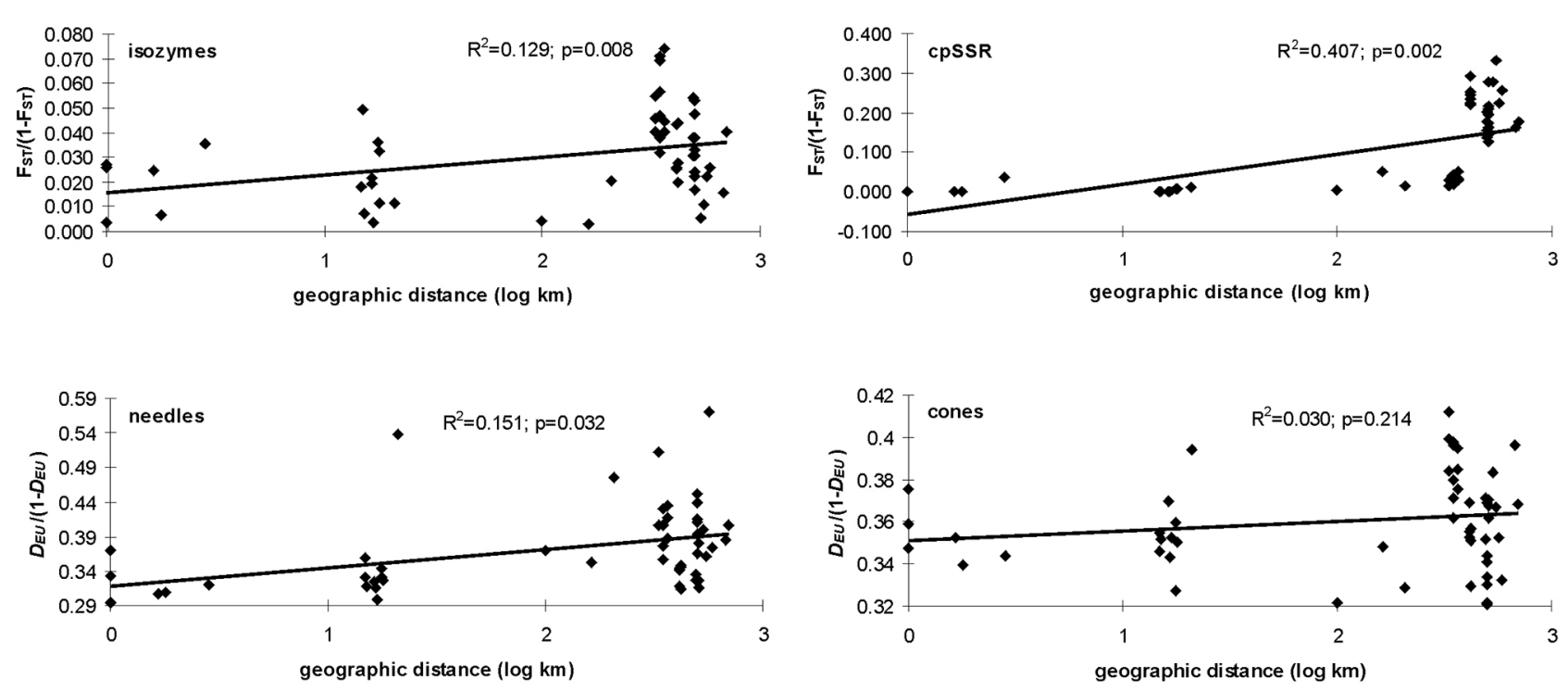

Fig. 5. Test of isolation by distance in P. mugo populations. Regression lines of linearized genetic distance vs. natural logarithm of geographic distance $(\mathrm{km})$ are shown. Pearson's correlation coefficients and p values after Mantel test with 9,999 random cycles are indicated.

2012). It also appeared similar to that reported for P. uncinata (Dzialuk et al. 2009), P. mugo complex (Heuertz et al. 2010) and P. mugo s.s. (Sannikov et al. 2011), in each case based on material sampled in their natural localities. A study on material collected from populations of P. mugo agg. introduced in Lithuania also showed a high level of diversity interpreted as origin from different mother regions (Danusevičius et al. 2013).

In this study we found greater diversity of P. mugo in the Alps than in other mountains in Central Europe. Similarly to our observations, Sannikov et al. (2011) found greater genetic diversity of $P$. mugo in the Alps $\left(A=2.9 ; H_{e}=0.305 ; H_{o}=0.310\right)$ compared to the Carpathians $\left(A=2.3 ; H_{e}=0.197 ; H_{o}=0.187\right)$. Greater genetic diversity in the Alps compared to the Apennines was also observed for Abies alba Mill. (Piovani et al. 2010), but the reverse relation was found for Pinus cembra L. (Höhn et al. 2009). The greater genetic diversity of $P$. mugo found in the Alps could result from 1) differentiation of the $P$. mugo populations during Pleistocene cold periods and independent, long lasting genetic processes in the isolated populations, which then came together in the Holocene (Thiel-Egenter et al. 2011), or 2) hybridisation between P. mugo and P. uncinata (Christensen 1987; Lewandowski et al. 2000).

The distribution of genetic within-population diversity that we found in P. mugo in Central Europe represents the classical postglacial colonization theory of "southern richness to northern purity" (Hewitt 2000), where glacial refugia harbour high levels of genetic diversity and recolonizing populations are usually composed of subsets of the genetic diversity present in the refugial source population (Comes and Kadereit 1998; Taberlet et al. 1998). Sequential founder effects, bottlenecks and long term isolation of populations within geographically separate refugia may lead to genetic differentiation due to drift (Provan and Bennett 2008). Unfortunately, the locations of glacial populations of $P$. mugo complex are poorly known.

Our finding is also in line with the "leading edge" concept, as concern the level of within-population genetic variation (Hampe and Petit 2005).

\section{Morphological variation}

Values of variation coefficients of morphological and anatomical characters of needles and cones for samples representing the Giant Mts., Tatras and Alps did not differ at a statistically significant level. Samples of $P$. mugo from the Giant Mts., the northernmost localities of the species (Jalas and Suominen 1973; Boratyński 1994), have similar levels of morphological variation as those from the central part of its geographic range (Staszkiewicz and Tyszkiewicz 1976; Boratyńska et al. 2005). Generally, cone characters are more variable than those of needles (Boratyńska et al. 2005), when the frequencies of sclerenchyma cells between vascular bundles and around resin canals are excluded. These data are strongly biased and extremely variable (Boratyńska and Boratyński 2007), which is also expressed in our data (Table 2).

The phenotypic characteristics of trees is an outcome of the interaction between the genetic constitution of the species and the environmental conditions. Nevertheless, in our data only a few among the analysed set of phenotypic traits of needles and cones revealed relations to geographic position and/ or climate conditions in place of origin. This can result from not too high differentiation of the site and 
climate conditions in the subalpine vegetation layer of the Alps, Tatras and Giant Mts. (Table 1), where P. mugo plant community is formed (Ozenda 1988; Jirásek 1996; Poldini et al. 2004; Tsaryk et al. 2006). Only the epidermal cells were higher and somewhat broader (EH and EW) on the sites with higher minimal temperatures during winter and lower precipitation during the summer season. The thicker epidermis and hypodermis may be an adaptation to winter and early spring frosts, which can desiccate the needles (Wieser and Tausz 2007), and/or to higher insolation and higher UV-radiation in the regions with less precipitation during the summer (Wieser 2007).

The only detected cone asymmetry (CPM/CCM) positive correlation to geographic longitude could have resulted from contact and possible hybridization between $P$. mugo with $P$. uncinata in the westernmost localities we sampled in the present study. Nevertheless, the cones were also more asymmetric in localities with higher temperatures in the hot and dry periods of the year, which is difficult to explain. It should be stressed that most of the analysed needle and cone traits were resistant to influences of climatic conditions.

The generally weak correlation of the analysed phenotypic traits to environmental factors could allow us to expect their genetic conditioning and, consequently, similar pattern of diversity, as was found using genetic markers. In reality, analyses of the morphological characters of cones and the morphological and anatomical characters of needles confirmed closer relations among populations within the three regions than between them (Fig. 3). In spite of the differences between the Alpine, Carpathian and Giant Mts. populations detected by Student's test and discrimination analysis (Table 2), only a few particular traits were responsible for a significant portion of the variance between these regions revealed by ANOVA (Table 5). A possible adaptation of morphological traits of needles and cones to the local environmental conditions of particular populations, although not fully confirmed in the present study, can be responsible for intermingled conglomerations on the NJ unrooted trees (Fig. 3) and PCoA scatter-plots (Fig. 4) constructed based on the phenotypic characteristics.

\section{Differentiation and genetic structure}

The analysis of genetic differentiation in P. mugo revealed slight differences among geographic regions in Central Europe (Dzialuk et al. 2012) but, as we expected, the recently introduced Jost $D$ estimator of population structure was significantly higher in this study for the more polymorphic chloroplast markers $\left(D_{\text {cPSSR }}=0.620\right)$ than for isozymes $\left(D_{\text {iso }}=0.013\right)$. Taking into account the very large number of private haplotypes in our study (above $74 \%$ ), the very low value of $G_{\text {ST c } P S R}=0.017$ seems to be a very biased estimator. Because traditional measures of differentiation (such as $G_{S T}$ ) can approach zero even if populations are completely differentiated, there is ongoing discussion about the new estimators of genetic population differentiation (Jost 2008; Gerlach et al. 2010).

In this study we used different types of genetic markers. Compared to nuclear markers, chloroplast DNA can better detect genetic structure because of its uniparental inheritance, nearly neutral evolution, low evolutionary rate, zero recombination and smaller effective population size than the nuclear genome (Provan et al. 1999; Wicke et al. 2011; Wachowiak et al. 2013). During the last few years, molecular data on cpDNA have been applied extensively in studies on the genetic diversity, population structure and phylogeography of $P$. mugo complex (Heuertz et al. 2010; Dzialuk et al. 2009, 2012; Danusevičius et al. 2013).

The weak taxonomic differentiation with clear phylogeographic structure in $P$. mugo s.l., identified using three cpSSRs by Heuertz et al. (2010), was only partially confirmed in our study. In fact, we found low but significant differentiation among mountain ranges by analysis of molecular variance (AMOVA), with 4 and $12 \%$ variation at the isozyme and chloroplast markers, respectively. Similarly, our estimates of the differentiation parameters were relatively low $\left(G_{\text {ST izo }}\right.$ $=0.027$ and $G_{S T \text { c } P S R R}=0.017$ ), as one would expect in species with extensive gene flow, a complex demographic history (Heuertz et al. 2010) and nonequlibrium genetic structure (Slavov and Zhelev 2004). Comparable or greater differentiation was observed in natural populations of P. mugo s.l $\left(G_{S T}=0.070\right.$, $\mathrm{F}_{S T}=0.076$, Heuertz et al. 2010), in P. mugo in the Carpathians and Alps $\left(\mathrm{F}_{S T}=0.069\right.$ and $\mathrm{F}_{S T}=0.036$, respectively, Sannikov et al. 2011) in P. mugo in Bulgaria $\left(\mathrm{F}_{S T}=0.041\right.$, Slavov and Zhelev 2004). However, in contrast to Heuertz et al. (2010), we didn't find phylogeographic structure in $P$. mugo populations; this may be an effect of the greater number of cpSSR loci used (nine versus three) and the smaller geographic area of our study and/or the taxonomy (P. mugo s.s. versus $P$. mugo s.l.).

It is well known that genetic variation is structured according to geography in P. mugo s.l. (Heuertz et al. 2010; Sannikov et al. 2011). More specifically, as we reported on cpSSR data (Dzialuk et al. 2012), vicariant gene pools for P. mugo s.s. lie in the Alps, Tatras Mts. and Giant Mts. Distinct vicariant gene pools for P. mugo complex can be expected on major mountain chains in the species range, similar to other conifers (Vendramin et al. 1999; Afzal-Rafii and Dodd 2007; Höhn et al. 2009). Although the absence of geographic structure of $P$. mugo was observed recently by Danusevičius et al. (2013) in plantations and by Wa- 
chowiak et al. (2013) in P. mugo complex, we found isolation by distance structure and clear geographic structure in the autochthonous populations. The results obtained using isozymes, DNA markers and morphological characters differed between populations of P. mugo sampled in the Alps, Tatras and Giant Mts. The cpSSR markers showed a closer connection between populations sampled in the Tatras Mts. and Giant Mts., while isozymes between the Tatras Mts. and Alps (Figs. 2 and 3). A close relation between the Alps and Tatras Mts. can be an effect of long distance pollen transportation by anticyclonic circulations in the Giant Mts. during May-June (Kwiatkowski and Hołdys 1985). The winds from the south and southwest, especially the dynamic foens, are able to transport $P$. mugo pollen from the Alps (Sjögren et al. 2008). As the chloroplast DNA in the species of the Pinaceae family is paternally inherited (Mogensen 1996), the connection between populations of $P$. mugo from the Alps and the Giant Mts. may be evidence of such long distance pollen transport. This kind of influence, however, could have been much greater during cold periods in the Pleistocene, when the $P$. mugo geographic range covered a much larger area than at present (Jankovská 2001; Latałowa et al. 2004; Jankovská 2008; Jankovská and Pokorný 2008) and the distances between the Alps and Giant Mts. centres of the species were shorter.

A closer connection between populations of P. mugo from the Alps and Tatras was detected by analysis of isozymes (Fig. 2), which are generally considered to be neutral (Kimura and Ohta 1974) and, therefore, suitable indicators to describe historical processes. In view of this, our result can be interpreted as a possible exchange of genes via small, cryptic refugia between the Tatras and Alps during the cold periods of the Pleistocene (Jankovská 2008; Jankovská and Pokorný 2008). Macrofossils of the species have been reported from the end of the Late Glacial Maximum (LGM) and early Holocene from altitudes of about $600 \mathrm{~m}$ in the West Carpathians (Obidowicz 1996; Rybníček and Rybníčková 2002). Unfortunately, the pollen of $P$. mugo has not been distinguished from that of $P$. sylvestris, making direct interpretation of palynological reports impossible (Burga 1988; Latałowa et al. 2004; Jankovská 2008). However, very high percentages of Pinus pollen, determined as "sylvestris" or "diploxylon" type, have frequently been interpreted as the presence of $P$. mugo, especially in records from the LGM and early Holocene in the mountainous regions (Latałowa et al. 2004). This suggests a broader area of distribution of $P$. mugo during the cold periods of the Pleistocene, similar to what was proposed for $P$. uncinata within the Iberian Peninsula (Ramil-Rego et al. 1998; Benito Garzón et al. 2007; Dzialuk et al. 2009).
In conclusion we can state that our study shows clear geographic structure despite low differentiation of $P$. mugo populations in Central Europe. The distribution of genetic diversity suggests northward movement of the species according to the postglacial colonization theory of "southern richness to northern purity". However, this should be viewed with caution and needs to be further confirmed, because of small number of geographic regions in the species range investigated. Meanwhile, paleobotanical evidence provides unambiguous support for glacial refugia of P. mugo s.l. in the Alps and Czech Republic.

\section{Acknowledgements}

We thank Ewa Sztupecka and Maria Ratajczak for technical assistance in the laboratory work, the Karkonosze and Tatra National Parks for assistance in plant material collection. This study has been financially supported by the Ministry of Science and Higher Education, grant No. 2 P06L 04628 and by the Institute of Dendrology.

\section{References}

Abbott R.J., Ritchie M.G., Hollingsworth P.M. 2008. Introduction. Speciation in plants and animals: pattern and process. Philosophical Transactions of the Royal Society Biological Sciences 363: 29652969. http://dx.doi.org/10.1098/rstb.2008.0096

Afzal-Rafii Z., Dodd R.S. 2007. Chloroplast DNA supports a hypothesis of glacial refugia over postglacial recolonization in disjunct populations of black pine (Pinus nigra) in western Europe. Molecular Ecology 16: 723-736. http://dx.doi. org/10.1111/j.1365-294X.2006.03183.x

Benito Garzón M., Sánchez de Dios R., Sáinz Ollero H. 2007. Predictive modelling of tree species distributions on the Iberian Peninsula during Last Glacial Maximum and Mid-Holocene. Ecography 30: 120-134. http://dx.doi.org/10.1111/j.09067590.2007.04813.x

Boratyńska K., Bobowicz M.A. 2001. Pinus uncinata Ramond taxonomy based on needle characters. Plant Systematics and Evolution 227: 183-194. http://dx.doi.org/10.1007/s006060170047

Boratyńska K., Boratyński A., Lewandowski A. 2003. Morphology of Pinus uliginosa (Pinaceae) needles from populations exposed to and isolated from the direct influence of Pinus sylvestris. Botanical Journal of the Linnean Society 142: 83-91. http:// dx.doi.org/10.1046/j.1095-8339.2003.00156.x

Boratyńska K., Boratyński A. 2007. Taxonomic differences among closely related pines Pinus sylvestris, $P$. mugo, $P$. uncinata, $P$. rotundata and $P$. uliginosa as revealed in needle sclerenchyma cells. Flora 
202: 555-569. http://dx.doi.org/10.1016/j.flora.2006.11.004

Boratyńska K., Marcysiak K., Boratyński A. 2005. Pinus mugo (Pinaceae) in the Abruzzi Mountains: high morphological variation in isolated populations. Botanical Journal of the Linnean Society 147: 309-316. http://dx.doi.org/10.1111/j.10958339.2005.00374.x

Boratyński A. 1994. Chronione i godne ochrony drzewa i krzewy polskiej części Sudetów, Pogórza i Przedgórza Sudeckiego. 7. Pinus mugo Turra i Pinus uliginosa Neumann. Arboretum Kórnickie 39: 63-85 (in Polish).

Burczyk J., Chałupka W. 1997. Flowering and cone production variability and its effect on parental balance in a Scots pine clonal seed orchard. Annals of Forest Science 54: 129-144. http://dx.doi. org/10.1051/forest:19970201

Burga C.A. 1988. Swiss vegetation history during last 18,000 years. New Phytologist 110: 581-602. http://dx.doi.org/10.1111/j.1469-8137.1988. tb00298.x

Chao A., Shen T.-J. 2010 Program SPADE (Species Prediction And Diversity Estimation). Program and User's Guide published at http://chao.stat. nthu.edu.tw

Cheliak W.M., Pitel J. 1984. Techniques for starch gel electrophoresis of enzymes from forest tree species. Information Report PI-X-42. Petawawa National Forestry Institute, Canada.

Christensen K.I. 1987. Taxonomic revision of the Pinus mugo complex and P. xrhaetica (P. mugo $\times$ P. sylvestris) (Pinaceae). Nordic Journal of Botany 7: 383-408. http://dx.doi.org/10.1111/j.1756-1051.1987. tb00958.x

Comes H.P., Kadereit J.W. 1998. The effect of Quaternary climatic changes on plant distribution and evolution. Trends in Plant Science 3: 432-438. http://dx.doi.org/10.1016/S13601385(98)01327-2

Comes H.P., Tribsch A., Bittkau C. 2008. Plant speciation in continental island floras as exemplified by Nigella in the Aegean Archipelago. Philosophical Transactions of the Royal Society B: Biological Sciences 363: 3083-3096. http://dx. doi.org/10.1098/rstb.2008.0063

Danusevičius D., Buchovska J., Stanys V., Šikšnianienė J.B., Baliuckas V., Brazaitis G. 2013. Chloroplast DNA polymorphism of an exotic P. mugo Turra population introduced to seaside spit of Kursiu Nerija in Lithuania. European Journal of Forest Research 132: 137-150. http://dx.doi. org/10.1007/s10342-012-0663-0

Dzialuk A., Boratyńska K., Boratyński A., Burczyk J. 2012. Geographic patterns of genetic diversity of Pinus mugo (Pinaceae) in Central European mountains. Dendrobiology 68: 31-41.
Dzialuk A., Muchewicz E., Boratyński A., Montserrat J.M., Boratyńska K., Burczyk J. 2009. Genetic variation of Pinus uncinata (Pinaceae) in the Pyrenees determined with cpSSS markers. Plant Systematics and Evolution 277: 197-205. http://dx.doi. org/10.1007/s00606-008-0123-y

Excoffier L., Lischer H.E.L. 2010. Arlequin suite ver 3.5: A new series of programs to perform population genetics analyses under Linux and Windows. Molecular Ecology Resources 10: 564-567. http:// dx.doi.org/10.1111/j.1755-0998.2010.02847.x

Felsenstein J. 1995. PHYLIP (Phylogeny inference package) version 3.5. Distributed by the author. Department of Genetics, University of Washington, Seattle.

Gerlach G., Jueterbock A., Kraemer P., Deppermann J., Harmand P. 2010. Calculations of population differentiation based on $G_{S T}$ and $D$ : forget $G_{S T}$ but not all of statistics! Molecular Ecology 19: 3845-3852. http://dx.doi.org/10.1111/j.1365294X.2010.04784.X

Goldstein D.B., Linares A.R., Cavallisforza L.L., Feldman M.W. 1995. An evaluation of genetic distances for use with microsatellite loci. Genetics 139: 463-471.

Gostyńska-Jakuszewska M. 1976. Pinus mughus Scop. In: Atlas Rozmieszczenia Drzew i Krzewów w Polsce. Browicz K. (ed.), 18: 5-9 + Map.

Hammer Ø., Harper D.A.T., Ryan P.D. 2001. PAST: Paleontological Statistics Software Package for Education and Data Analysis. Palaeontologia Electronica 4: 1-9.

Hampe A., Petit R.J. 2005. Conserving biodiversity under climate change: the rear edge matters. Ecology Letters 8: 461-467. http://dx.doi. org/10.1111/j.1461-0248.2005.00739.x

Hamrick J.L., Godt M.J.W. 1996. Effects of life history traits on genetic diversity in plant species. Philosophical Transactions of the Royal Society B: Biological Sciences 351: 1291-1298. http://dx. doi.org/10.1098/rstb.1996.0112

Heuertz M., Teufel J., González-Martínez S.C., Soto A., Fady B., Alía R., Vendramin G.G. 2010. Geography determines genetic relationships between species of mountain pine (Pinus mugo complex) in western Europe. Journal of Biogeography 37: 541-556. http://dx.doi.org/10.1111/j.13652699.2009.02223.x

Hewitt G. 2000. The genetic legacy of the Quaternary ice ages. Nature 405: 907-913. http://dx.doi. org/10.1038/35016000

Hewitt G.M. 1996. Some genetic consequences of ice ages, and their role in divergence and speciation. Biological Journal of the Linnean Society 58: 247-276. http://dx.doi. org/10.1111/j.1095-8312.1996.tb01434.x 
Hijmans R.J, Guariano L., Mathur P. 2012. DIVA-GIS manual, ver. 7.5. www.diva-gis.org

Höhn M., Gugerli F., Abran P., Bisztray G., Bounamici A., Cseke K., Hufnagel L., Quintela-Sabarís C., Sebastiani F., Vendramin G.G. 2009. Variation in the chloroplast DNA of Swiss stone pine (Pinus cembra L.) reflects contrasting post-glacial history of populations from the Carpathians and the Alps. Journal of Biogeography 36: 1798-1806. http:// dx.doi.org/10.1111/j.1365-2699.2009.02122.x

Idury R.M., Cardon L.R. 1997. A simple method for automated allele binning in microsatellite markers. Genome Research 7: 1104-1109.

Jalas J., Suominen J. 1973. Atlas Florae Europaeae 2. Committee for Mapping the Flora of Europe and Societats Biologica Fennica Vanamo, Helsinki.

Jankovská V., Pokorný P. 2008. Forest vegetation of the last full-glacial period in the Western Carpathians (Slovakia and Czech Republic). Preslia 80: 307-324.

Jankovská V. 2001. Vegetation development in the western part of the Giant Mts. during the Holocene. Opera Corcontica 38: 11-19.

Jankovská V. 2008. Slovak and Moravian Carpathians in the last glacial period - an island of "Siberian taiga" in Europe. Phytopedon 7: 122-130.

Jirásek J. 1996. Společenstva kosodřeviny (Pinus mugo) v České republice. Preslia 68: 1-12.

Johansen S. 1991. Airborne pollen and spores on the Arctic island of Jan Mayen. Grana 30: 373-379. http://dx.doi.org/10.1080/00173139109431993

Jost L. 2008. $\mathrm{G}_{\mathrm{ST}}$ and its relatives do not measure differentiation. Molecular Ecology 17: 4015-4026. http://dx.doi.org/10.1111/j.1365294X.2008.03887.x

Kalinowski S.T. 2009. How well do evolutionary trees describe genetic relationships among populations? Heredity 102: 506-513. http://dx.doi. org/10.1038/hdy.2008.136

Kimura M., Ohta T. 1974. On some principles governing of molecular evolution. Proceedings of the National Academy of Sciences USA 71: 28482852. http://dx.doi.org/10.1073/pnas.71.7.2848

Koski V. 1970. A study of pollen dispersal as a mechanism of gene flow in conifers. Communicationes Instituti Forestalis Fenniae 70: 1-78.

Kwiatkowski J., Hołdys T. 1985. Climate. In: Karkonosze polskie. Jahn A. (ed.). Wydawnictwo Polskiej Akademii Nauk, Wrocław, pp. 87-116. (in Polish).

Latałowa M., Tobolski K., Nalepka D. 2004. Pinus L. subgenus Pinus (subgen. Diploxylon (Koehne) Pilger) - Pine. In: Late glacial and holocene history of vegetation in Poland based on isopollen maps. Ralska-Jasiewiczowa M. (ed.). W. Szafer Institute of Botany, Kraków, pp. 165-177.
Lewandowski A., Boratyński A., Mejnartowicz L. 2000. Allozyme investigations on the genetic differentiation between closely related pines - Pinus sylvestris L., P. mugo Turra, P. uncinata Ramond ex DC. and P. uliginosa Neumann (Pinaceae). Plant Systematics and Evolution 221: 15-24. http://dx. doi.org/10.1007/BF01086377

Lewis P.O., Zaykin D. 2001. Genetic Data Analysis V1.1. http://www.eeb.uconn.edu/people/plewis/ software.php.

Liu K.J., Muse S.V. 2005. PowerMarker: an integrated analysis environment for genetic marker analysis. Bioinformatics 21: 2128-2129. http://dx.doi. org/10.1093/bioinformatics/bti282

Marcysiak K., Boratyński A. 2007. Contribution to the taxonomy of Pinus uncinata Ram. (Pinaceae) based on cone characters. Plant Systematics and Evolution 264: 57-73. http://dx.doi.org/10.1007/ s00606-006-0501-2

Mogensen L.H. 1996. The hows and whys of cytoplasmic inheritance in seed plants. American Journal of Botany 83: 383-404. http://dx.doi. org $/ 10.2307 / 2446172$

Morgante M., Felice N., Vendramin G.G. 1998. Analysis of hyper-variable chloroplast microsatellites. In: Pinus halepensis reveals a dramatic bottleneck. Molecular tools for screening biodiversity: plants and animals. Karp A. (ed.). Chapman and Hall, London, pp. 402-412.

Mousadik A., Petit R.J. 1996. High level of genetic differentiation for allelic richness among populations of the argan tree [Argania spinosa (L) Skeels] endemic to Morocco. Theoretical and Applied Genetics 92: 832-839. http://dx.doi.org/10.1007/ BF00221895

Nei M. 1972. Genetic distance between populations. American Naturalist 106: 283-292. http://dx.doi. org/10.1086/282771

Obidowicz A. 1996. A late glacial-holocene history of the formation of vegetation belts in the Tatra Mts. Acta Paleobotanica 36: 159-206.

Odrzykoski I. 2002. Investigations of genetic variation of Pinus mugo using biochemical and molecular markers. Adam Mickiewicz University, Poznań (in Polish).

Ozenda P. 1988. Die Vegetation der Alpen im europäischen Gebirgsraum. Fischer, Stuttgart, New York.

Pastorino J.M., Gregorius H.-R. 2002. How many macrogametophytes per individual should be analysed to genotype conifer seed trees at genetic markers. Forest Genetics 9: 47-53.

Peakall R., Smouse P.E. 2006. GenAlEx 6: genetic analysis in Excel. Population genetic software for teaching and research. Molecular Ecology Notes 6: 288-295. http://dx.doi.org/10.1111/j.14718286.2005.01155.x 
Peakall R., Smouse P.E. 2012. GenAlEx 6.5: genetic analysis in Excel. Population genetics software for teaching and research - an update. Bioinformatics 28: 2537-2539. http://dx.doi.org/10.1093/bioinformatics/bts 460

Piovani P., Leonardi S., Piotti A., Menozzi P. 2010. Conservation genetics of small relic populations of Silver fir (Abies alba Mill.) in northern Apennines. Plant Biosystems 144: 683-691. http://dx. doi.org/10.1080/11263504.2010.496199

Poldini L., Oriolo G., Francescato C. 2004. Mountain pine scrubs and heaths with Ericaceae in the south-eastern Alps. Plant Biosystems 138: 53-85. http://dx.doi.org/10.1080/11263500410001684 125

Pons O., Petit R.J. 1996. Measuring and testing genetic differentiation with ordered versus unordered alleles. Genetics 144: 1237-1245.

Provan J., Bennett K.D. 2008. Phylogeographic insights into cryptic glacial refugia. Trends in Ecology and Evolution 23: 564-571. http://dx.doi. org/10.1016/j.tree.2008.06.010

Provan J., Soranzo N., Wilson N.J., Goldstein D.B., Powell W. 1999. A Low Mutation Rate For Chloroplast Microsatellites. Genetics 153: 943-947.

Prus-Głowacki W., Bączkiewicz A., Wysocka D. 2005. Clonal structure of small isolated populations of Pinus mugo Turra from peatbogs in the Tatra Mts. Acta Biologica Cracoviensia Series Botanica 47: 53-59.

Prus-Głowacki W., Bujas E., Ratyńska H. 1998. Taxonomic position of Pinus uliginosa Neumann as related to other taxa of Pinus mugo complex. Acta Societatis Botanicorum Poloniae 67: 269-274. http://dx.doi.org/10.5586/asbp.1998.035

Ramil-Rego P., Muñoz-Sobrino C., Rodríguez-Guitián M., Gómez-Orellana L. 1998. Differences in the vegetation of the North Iberian Peninsula during the last 16,000 years. Plant Ecology 138: 4162. http://dx.doi.org/10.1023/A:1009736432739

Ridgeway G.J., Sherburne S.W., Lewis R.D. 1970. Polymorphism in esterases of Atlantic herring. Transactions of the American Fisheries Society 99: 147-151. http://dx.doi.org/10.1577/1548-86 59(1970) $99<147:$ PITEOA > 2.0.CO;2

Rybníček K., Rybníčková E. 2002. Vegetation of the Upper Orava region (NW Slovakia) in the last 11000 years. Acta Paleobotanica 42: 153-170.

Sannikov S.N., Petrova I.V., Schweingruber F., Egorov E.V., Parpan T.V. 2011. Genetic differentiation of Pinus mugo Turra and Pinus sylvestris L. populations in the Ukrainian Carpathians and the Swiss Alps. Russian Journal of Ecology 42: 270-276. http:// dx.doi.org/10.1134/S1067413611040151

Siciliano M.J., Shaw C.R. 1976. Separation and visualization of enzymes on gels. Chromatographic and electrophoretic techniques. Heinemann, London, pp. 185-209.

Sjögren P., Van der Knaap W.O., Huusko A., van Leeuwen J.F.N. 2008. Pollen productivity, dispersal, and correction factors for major tree taxa in the Swiss Alps based on pollen-trap results. Review of Paleobotany and Palynology 152: 200-210. http:// dx.doi.org/10.1016/j.revpalbo.2008.05.003

Slavov G.T., Zhelev P. 2004. Allozyme variation, differanation and inbreeding in populations of Pinus mugo in Bulgaria. Canadian Journal of Forest Research 34: 2611-2617. http://dx.doi. org/10.1139/x04-127

Smouse P.E., Dyer R.J., Westfall R.D., Sork V.L. 2001. Two generation analysis of pollen flow across a landscape. I. Male gamete heterogeneity among females. Evolution 55: 260-271. http://dx.doi. org/10.1111/j.0014-3820.2001.tb01291.x

Sobierajska K., Boratyńska K. 2008. Variability of needle characters of Pinus mugo Turra populations in the Karkonosze Mountains in Poland. Dendrobiology 59: 41-49.

Sobierajska K., Marcysiak K., Boratyńska K. 2010. Differentiation of Pinus mugo Turra (Pinaceae) populations in the Giant Mountains (Karkonosze, Sudetes) on the basis of cone characters. Dendrobiology 63: 33-41.

Sokal R.S., Rohlf F.F. 2003. Biometry. $3^{\text {rd }}$ W.H. Freeman (ed.), New York.

Staszkiewcz J., Tyszkiewicz M. 1976. Zmienność populacyjna i osobnicza szyszek kosodrzewiny (Pinus mugo Turra) ze szczególnym uwzględnieniem materiałów z Karpat. Fragmenta Floristica et Geobotanica 22: 19-29. (in Polish)

Staszkiewicz J. 1968. Investigations on Pinus silvestris L. from South-Eastern Europe and from Caucasus and its relation to the pine from the other territories of Europe based on morphological variability of cones. Fragmenta Floristica et Geobotanica 14: 259-315 (in Polish with English summary).

Sugita S., Gaillard M.-J., Broström A. 1999. Landscape openness and pollen records: a simulation approach. The Holocene 9: 409-421. http://dx. doi.org/10.1191/095968399666429937

Tabachnik B.G., Fidell L.S. 2007. Using Multivariate Statistics. $5^{\text {th }}$ edition. California State University, Northridge.

Taberlet P., Fumagalli L., Wust-Saucy A.G., Cosson J.F. 1998. Comparative phylogeography and postglacial colonization routes in Europe. Molecular Ecology 7: 453-464. http://dx.doi.org/10.1046/ j.1365-294x.1998.00289.x

Thiel-Egenter C., Alvarez N., Holderegger R., Tribsch A., Englisch T., Wohlgemuth T., Colli L., Gaudeul M., Gielly L., Jogan N., Linder H.P., Negrini R., Niklfeld H., Pellecchia M., Rioux D., Schönswetter P., Taberlet P., van Loo M., Winkler M., IntraBio- 
Div Consortium, Gugerli F. 2011. Break zones in the distributions of alleles and species in alpine plants. Journal of Biogeography 38: 772-782. http://dx.doi.org/10.1111/j.13652699.2010.02441.x

Tsaryk I., Didukh Ya P., Tasenkevich L., Waldon B., Boratyński A. 2006. Pinus mugo Turra (Pinaceae) in the Ukrainian Carpathians. Dendrobiology 55: 39-49.

Vendramin G.G., Degen B., Petit R.J., Anzidei M., Madaghiele A., Ziegenhagen B. 1999. High level of variation at Abies alba chloroplast microsatellite loci in Europe. Molecular Ecology 8: 1117-1126. http://dx.doi.org/10.1046/j.1365294x.1999.00666.x

Wachowiak W., Boratyńska K., Cavers S. 2013. Geographical patterns of nucleotide diversity and population differentiation in three closely related European pine species in the Pinus mugo complex. Botanical Journal of the Linnean Society 172: 225-238. http://dx.doi.org/10.1111/boj.12049

Wicke S., Schneeweiss G., de Pamphilis C., Müller K., Quandt D. 2011. The evolution of the plastid chromosome in land plants: gene content, gene order, gene function. Plant Molecular Biology 76: 273-297. http://dx.doi.org/10.1007/s11103011-9762-4

Wieser G., Tausz M. 2007. Current concept for treelife limitation at the upper timberline. In: Trees at their upper limit. Wieser G., Tausz M. (eds.). Springer, Dordrecht, pp. 1-18. http://dx.doi. org/10.1007/1-4020-5074-7_1

Wieser G. 2007. Climate at the upper timberline. In: Trees at their upper limit. Wieser G., Tausz M. (eds.). Springer, Dordrecht, pp. 19-36. http:// dx.doi.org/10.1007/1-4020-5074-7_2

Willis K.J., Rudner E., Sümegi P. 2000. The full-glacial forest of central and southern Europe: evidence from Hungarian macrofossil charcoal, pollen and molluscan records. Quaternary Science Revue 53: 203-213. http://dx.doi.org/10.1006/ qres.1999.2119

Wolfrath B., Hannon G., Feurdaean A., Ghergari L., Onac B.P., Posnert G. 2001. Reconstruction of climatic and environmental changes in NW Romania during the early part of the last deglaciation (15 000-13 000 cal yr BP). Quartenary Sciences Revue 20: 1897-1914. http://dx.doi.org/10.1016/ S0277-3791(01)00014-2

Wright S. 1943. Isolation by distance. Genetics 28: 114-138.

Young A., Boyle T., Brown T. 1996. The population genetic consequences of habitat fragmentation for plants. Trends in Ecology and Evolution 11: 413-418. http://dx.doi.org/10.1016/0169$5347(96) 10045-8$

Zar J.H. 1999. Botanical analysis. Prentice Hall, New Jersey. 